\title{
Sınır Bölgelerinde Sosyo-Mekânsal Etkileşim ve Yönetişim: Türkiye Örneği ${ }^{*}$
}

\author{
Emrah Söylemez ${ }^{1}$ \\ ORCID: 0000-0003-4150-3184
}

\author{
Çiğdem Varol ${ }^{2}$ \\ ORCID: 0000-0002-2432-5745
}

\section{Öz}

Ulus devlet sınırlarının geçirgenliklerinin artması ile sınır bölgeleri eskiye kıyasla daha yoğun mal ve insan akışına ev sahipliği yapmakta ve çeperde kalan dışlanmış mekânlar olmak yerine, daha merkezi ve önemli aktivitelerin mekânlarna dönüşmektedir. Hacimsel olarak artan etkileşimler, sinırın çok boyutlu ve analitik olarak değerlendirilmesini ve bu çerçevede ortak yönetişim arayışların gündeme getirmiştir. Bu kapsamda Türkiye'nin ulusal sinırlarındaki, sınır ötesi ekonomik, sosyal, idari ve mekânsal etkileşim seviyelerinin, merkezi düzeyde elde edilebilen nesnel göstergeler yardımıyla ölçülmesi, etkileşimin görece yüksek seviyede olduğu sınır bölgelerinde sosyo-mekânsal etkileşim biçimlerinin ă̆ analiz yöntemleri ile tanımlanması ve sınır bölgelerinin özgün nitelikleri bağlamında ortak yönetişim çerçevesi geliştirilmiştir. Bu çalışma ile; sınır bölgeleri için ulusal düzeyde Çok Değişkenli Sınır Geçirgenlik Endeksi (ÇDSGE) geliştirilmiştir. Yapulan ă̆ analizleri, sinır bölgelerindeki merkezi yerleşimlerinin ă̆ karakterlerine bağhl olarak farklılaştığını, sınır bölgelerinin etki alanını literatürde ve uygulamadaki mesafelerin ötesine geçebildiğini, sınırn mekânsal etki alanı dışında bulunan ulusal düzeyde merkezi özellik taşıyan yerleşmelerin de sınır ötesi ile önemli derecelerde ilişkilerinin olduğunu ortaya çıkarmıştır. Yönetişim boyutunda ise, kırllganlık ve komşu devletler arasındaki hassas dengelerin sinır bölgeleri için kuvvetli bir yönetişim çerçevesinin sürdürülmesine olanak să̆layamadı̆̆ı ve bu çerçevede sınır bölgeleri için "ortak yönetişim aralı̆̆ı" kavramının önemi vurgulanmıştır.

Anahtar Kelimeler: Sınır bölgeleri, sosyo-mekânsal etkileşim, yönetişim, Türkiye, AB, Gürcistan

\footnotetext{
* Bu yazı İlhan Tekeli Tez Ödülleri kapsamında 2017-2018 Doktora Tez ödülünü alan Dr. Emrah Söylemez'in 2017 yılında Gazi Üniversitesi Fen Bilimleri Enstitütüsü'nde Prof. Dr. Çiğdem Varol Özden danışmanlığında tamamladığı “Sınır Bölgelerinde Sosyo-Mekânsal Etkileşim ve Yönetişim: Türkiye' nin AB ve Gürcistan Sınır Bölgeleri" isimli tez çalışmasından yararlanılarak hazırlanmıştır.

${ }^{1}$ Dr., Çevre ve Şehircilik Bakanlığı, E-mail: emrah.soylemez@csb.gov.tr

${ }^{2}$ Prof. Dr., Gazi Üniversitesi, E-mail: cvarol@gazi.edu.tr

idealkent @ Kent Araştırmaları Dergisi (Journal of Urban Studies)

http://idealkentdergisi.com

Geliş Tarihi Received Date: 24.03.2020 Kabul Tarihi Accepted Date: 25.04.2020
} 


\title{
Socio-Spatial Interaction and Governance in Border Regions: The Case of Turkey
}

\author{
Emrah Söylemez ${ }^{3}$ \\ ORCID: 0000-0003-4150-3184
}

*

\author{
Çiğdem Varol ${ }^{4}$ \\ ORCID: 0000-0002-2432-5745
}

\begin{abstract}
With the increased permeability of the nation state borders, border regions host more intense flows of goods and people when compared to the past and turn into spaces of more central and important activities, instead of being excluded places in the periphery. The growing volumetric interactions have led to a multi-dimensional and analytical assessment of the border regions. In this respect, it is aimed to measure the cross-border economic, social, administrative and spatial interaction levels in Turkey's national borders with the help of objective indicators that can be obtained at the central level; to define the socio-spatial interaction forms by network analysis in the border regions where the interaction is relatively high; and to develop a governance framework in the context of the specific characteristics of the regions. With this research; Multivariate Border Permeability Index was developed to measure border permeability at the national level. The network analysis; revealed that the central settlements in the border regions differed depending on the characteristics of the network, the spatial domain of the border regions could go beyond the distances in the literature and in practice, and the settlements that had central features at the national level but outside the spatial domain of the border had significant relations with the cross-border. In the governance dimension, the importance of the concept of "common governance gap" for the border regions was emphasized that vulnerability and sensitive balances between neighbor states do not allow a strong governance framework to be maintained for border regions
\end{abstract}

Keywords: Border regions, socio-spatial interaction, governance, Turkey, the EU, Georgia

${ }^{3}$ Dr., Ministry of Environment and Urbanization, E-mail: emrah.soylemez@csb.gov.tr

${ }^{4}$ Prof. Dr., Gazi University, E-mail: cvarol@gazi.edu.tr

idealkent @ Kent Araştırmaları Dergisi (Journal of Urban Studies)

http://idealkentdergisi.com

Geliş Tarihi Received Date: 24.03.2020 Kabul Tarihi Accepted Date: 25.04.2020 


\section{Giriş}

Toplumların çizilmiş sınırlar içerisinde yaşaması, ilkel topluluklardan günümüze değin öncelikle güvenlik kaygısı (Grosby, 1995) olmak üzere çeşitli nedenler ve işlevlerle ortaya çıkmıştır. Modern toplumlarda sınır, 18.yy ile birlikte ulus devletlerin inşası ile sonuçlanan politik oluşumları ifade etmek üzere kullanılmış; modern ulus devlet ve küresel sistemde ise, politik bölünme veya sosyal yapıların ürünü olarak tanımlanmıştır (Baud ve Schendel, 1997). Sınır literatürünün 1970'li yıllardaki coğrafi ve işlevsel yaklaşımlar çerçevesindeki ilk evrelerinde yapılan çalışmalarda devlet sınırları, barışı sağlama ve koruma fikri çerçevesinde uluslararası çatışmalardaki rolü ile ele alınmıştır (Kolossov, 2005). 1980 ve sonrasındaki yıllar, yaklaşımların çeşitlendiği ve sınırın çok boyutlu olarak ele alındığı dönemler olarak değerlendirilebilir. Bu dönemde küresel sistem ve bölgesel kimlikler yaklaşımı, jeopolitik yaklaşım, sosyal yaklaşım, sınır yönetimi ve işbirliği yaklaşımları, çevresel konular ağırlıklı modellemeler ve kavramsallaştırmalar ile uluslararası ticaret öne çıkan konular olmuştur (Hansen vd., 1981; Hooghe 1996; Krugman, 1992). 2000 sonrası süreçte ise; sosyal bilimciler ulus devlet ve sınırını, sosyal ve ekonomik ilişkiler bağlamında tanımlamış; yaşanan küreselleşme ile birlikte sınır kavramını klasik anlamdaki bariyer tanımlaması dışında, insanların ve malların kolay geçişini ifade eden mobilite, akışkanlık ve melezlik kavramları ile kullanmaya başlamışlardır. Bu dönemde bölgelerin dinamik ve statik özellikleri üzerinden avantajları, uluslararası ticaret alanındaki konumları ile sosyal ve beşerî sermaye konularında değerlendirmeler yapılmıştır (Diener ve Hagen, 2012, Haselsberger, 2014, Kolejka vd., 2015, Paasi, 2005; Popescu, 2006).

Hansen vd. (1981) ve Sassen (2001) sınır mekânını merkezi yerler kuramı bağlamında "kentler hiyerarşisi" çerçevesinde ele almışlardır. Küreselleşmenin ürettiği kentler hiyerarşisi, karmaşık ağlar içeren bir üretim sistemidir. Kentler ise bu sistemde ulusal kimliklerinden çok uluslararası kimlikleri ve ürettikleri ile ön plandadır (Sassen, 2001). Bu durum uluslararası ticaretin gerçekleştiği sınır bölgelerini daha da önemli hale getirmektedir. Bu kapsamda uluslararası literatürde sınır kavramı, bir hat olarak ifade edilen sinır kavramından, belirli bir bölgeyi ifade eden, sosyal ve ekonomik farklılıkların iletişim kurdukları eylem mekânlarına evrilmiştir (Van Houtum, 2005; Waterhout, 2010). Üzerinde çeşitli sosyo-mekânsal etkileşimlerin oluştuğu bu özel alanlar, devletleri birbirinden ayıran ve egemenliklerini pekiştiren çok katmanll, karmaşık ve seçici geçirgenliğe sahip niteliktedir. Martinez (2004) 
bölgesel düzeyde etkileşimlere sahip olması nedeniyle bu alanlar için "sınır bölgesi" kavramsallaştırmasını önermektedir. Bu tanımlama yapısal olarak komşu sınırdaki sosyo-mekânsal akımlarla birlikte oluşan sınır geçirgenliğini, sınırın her iki tarafının farklı dinamikler ile var olan ağlarını ve sınır bölgelerinin özel koşullarına yönelik idari yapılanma ve kurumsallaşma biçimlerini ortaya koymaktadır.

Sınırdaki sosyo-mekansal nitelikli akımlara paralel olarak sınır hattının geçirim düzeyi, miktarı ve şartlarının ölçülmesi (Harrison, 2012) ile sınır geçirgenliği analitik olarak ortaya konabilmektedir. Geçirgenliğin çeşitli parametreler ile ölçülmesi sınır bölgelerindeki bağlantısal ilişkinin anlaşılması açısından ilk basamaktır. Böylelikle farklı geçirgenlik düzeylerine sahip sınır bölgeleri için bir değerlendirme çerçevesi ortaya konulabilmektedir. Söz konusu geçirim devletin egemenlik hakları çerçevesinde ekonomik, sosyal, idari ve mekânsal ayakları olan bir akımlar bütünüdür. Sınırın diğer tarafı ile ilişkili akımları seçerek geçiren sınır bölgeleri, birbiriyle bağlantılı ağ tabanlı bir yapıya dönüşmektedir (Jessop, Brenner ve Jones, 2008; Paasi, 2005). Ağ tabanlı bu yapıların farklı dokulara sahip olması ve bu durumun ölçülen geçirgenlik düzeyleri ve bölgenin özgün karakteri ile birleşmesiyle sınır bölgelerine özgü yönetişim yaklaşımlarının irdelenmesi ve tartışılması potansiyelini yaratmaktadır. Bu durumda, öncelikle sınır mekânının etki alanının sınır geçirgenliği ölçülerek tanımlanması, mekân üzerindeki ağsal ilişkilerin analiz edilerek akımlara ilişkin bilginin elde edilmesi ve sınırdaki aktörlerin değerlendirmelerinin çok boyutlu olarak yapılması önem arz etmektedir (Painter, 2000).

Sınır kavramının taşıdığı farklı ve karmaşık içerikler ile birlikte sınırın çok katmanlı ve disiplinlerarası ele alınısı, sınırın kavramlaştırılmasında idari, jeo-politik, kültürel, ekonomik ve sosyal boyutları gündeme getirmiştir (Donnan ve Wilson, 1999; Haselsberger, 2014; Newman, 2003; Paasi, 2005; Popescu, 2006; Scott; 2000). Sınırlar jeopolitik, sosyo-kültürel, ekonomik ve mekânsal yönleri, süreçleri ve güç ilişkilerini tanımlamakta, sınıflamakta ve kontrol etmektedir. Sınır, akışkan niteliği sayesinde (Bauman, 1999) mekânsal ve zamansal olarak biçim değiştirmektedir. Bu çerçevede yapılan çalışmalarda sınırın fiziksel ayırıcı olarak rolü incelenirken, değişken doğası göz ardı edilmektedir. Sınır ötesi ilişki analizlerinde temel belirleyici fonksiyon olan "geçirgenlik", sınırın mekândaki niteliğine göre farklılaşmakta ve farklı ölçeklerde analizleri gerektirmektedir. Sınırı salt fiziksel bir yaklaşım üzerinden değil, jeopolitik, sosyo-mekansal, sosyo-kültürel, ekonomik, güvenlik 
gibi ulus devletler sınırlarına ilişkin oluşan çerçevedeki düzlemlerini olabildiğince kapsayan ve bu çerçevede ekonomik, sosyal, yönetsel ve mekânsal boyutları dikkate alan bir analiz biçimi, sınır bölgesinin bir üst kavrama dönüşmesine katkı sağlayacaktır.

\section{Geçirgenlik ve Boyutları}

Geçirgenlik (permeability) kelimesinin kökeni Fransızca ve Latince sözlüklerde 1580'li yıllara kadar gitmekte ve temelde, içinden geçilen, arasından geçilen gibi anlamlar içermektedir. Uygulamalı bilimler başta olmak üzere, sosyal bilimlerde de kullanılan kavram, sınır ile ilgili çalışmalarda, farklı modlar arası geçişi ifade edecek şekilde kullanılmıştır (Nathalie, 2006). Fizik, akışkanlar mekaniği, uzay bilimleri gibi uygulamalı bilimlerde özel tanımları yapılmış olan ve ölçülebilen bir kavram olan geçirgenlik, benzetim yoluyla sosyal bilimlere geçmiş, ancak ölçmeye yönelik bütüncül bir çerçeve geliştirilememiştir.

Çok disiplinli çalışmalara konu olan sınır literatüründe "geçirgenlik" kavramı ulus devletlerin ortaya çıkması ile birlikte farklı boyutları ile ele alınmıştır. Başlangıçta ulus devletlerin korumacı yapısına uygun olarak güvenlik temelli geçirgenlik çalışmaları gündeme gelmiştir. Bu yaklaşım temelde sınır çizgisinin diğer tarafından kendi belirlediği ölçütlere uygun olanları geçiren, kimi zaman hiç geçirmeyen bir idari/politik sınır yönetim biçimidir. Fiziksel engeller ve kontrol noktaları temel araçlar olarak kurgulanmıştır. Merkezi hükümetler sınır mekânını politik ve askerî açıdan değerlendirerek sosyal ve ekonomik boyutlarını ikinci plana atmaktadır (Anderson ve O'Dowd, 1999). Bu göz ardı edilme durumu, sınırı ekonomik ve sosyal olarak daha da çeperde konumlandırır. Bu nedenle güvenlik temelli yapılan geçirgenlik analizleri ulus devlet sınılarındaki kaçak geçişler, denetim altında olmayan geçişler ve bunların mekânsal analizi şeklinde oluşmuştur (Nathalie, 2006). Diğer yandan sınır geçirgenliğini sadece jeopolitik düzeyde etkileşim kolaylığ olarak değil (Starr ve Thomas, 2001), sinırın yasal, coğrafi, tarihi ve sosyal kimlikleri üzerinden insanlar, mal, sermaye, fikir vb. tarafindan oluşturulan baskının ürünü olarak tanımlayan çalışmalar da (Stephenne ve Pesaresi, 2006) yapılmıştır. Bu çalışmalarda sınır geçirgenliğinin açıklık, akımların geçişi, sınır işbirlikleri gibi kavramlarla birlikte sınırın bariyer özelliğine karşı bir ifade olarak kullanıldığı da görülmektedir. 
Bu çerçevede geçirgenlik ile ilgili yapılan çalışmaları; sınır geçişini engelleyici veya kıstllayıc önlemler ile birlikte değerlendiren güvenlik temelli yaklaşımlar, sınır bölgelerinde oluşan formel ve enformel ilişki türlerini dikkate alan ekonomik ilişki ve akımları ön planda tutan sosyal ve ekonomik geçirgenlik temelli yaklaşımlar ile mekânsal eşiklerin geçirgenliğe etkilerini analitik öğeler ile ölçen coğrafi tabanlı yaklaşımlar olmak üzere üç temel başlıkta sınıflandırabiliriz. Bu üç yaklaşım kendi içlerinde tutarlı ve sınırdaki geçirgenliği ortaya koyan önemli çalışmalar olmakla beraber, hepsinin bir arada değerlendirildiği bütüncül bir sınır geçirgenliği modeli ortaya koyamamaktadır.

Sınır bölgeleri, ulus devletler arasında doğal ve yapay eşiklerle fiziksel olarak belirlenmiş sınır hatları ve hudut kapıları etrafında, sınırın geçirgenliği ile nitelendirilen aktivite mekanları olarak tanımlanabilirler. Sınırın diğer tarafına geçişler formel yollar ile çeşitli kurallar çerçevesinde gerçekleşirken, bu süreçte kontrolsüz geçişler ve geçiş teşebbüsleri de olabilmektedir (Şekil 1).

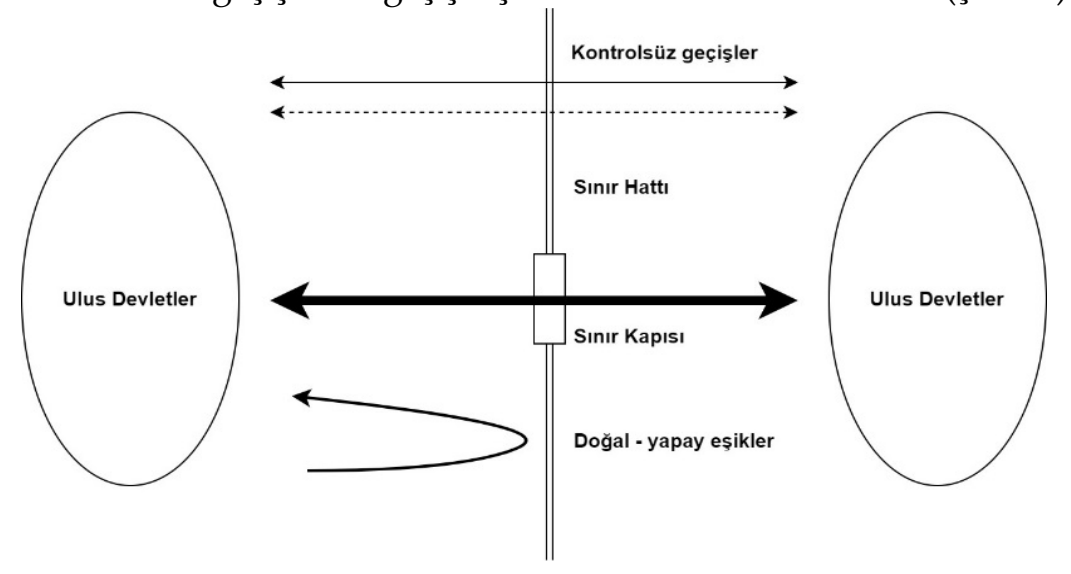

Şekil 1. Sınırda meydana gelen akımlar

Geçirgenlik ekonomik, sosyal, idari ve mekânsal boyutlar ile tanımlanabilen ve tekil değerlerin birleştirilmesi ile elde edilebilen bir kavramdır. Bu çerçevede bir geçirgenlik türü olan ekonomik geçirgenlik temelde yerli ve yabancı sermaye arasındaki bağı sağlayan bir faktör olarak tanımlanmaktadır (Castel-Branco, 2014). Bu kapsamda ulus devlet sınırlarında ekonomik geçirgenliğin belirleyicileri olarak; ekonomik akımların karşılıklı olarak diğer tarafa geçiş hacimleri, yerli ve yabancı sermayenin yer seçimi, pazarlara yakınlık gibi göstergeler referans alınmıştır. Sınır üzerinden gerçekleştirilen ticaret, 
ülkeler arası yatırım hacimleri (karşılıklı doğrudan yabancı yatırımları), sınırda ekonomik hareketliliğin sürdürülmesini sağlayan hudut kapılarındaki gümrük işlemlerindeki kolaylık ve hızlılık ve ülkeler arasındaki mal alım satımlarının dengesi geçirgenliğin ekonomik boyutlarını yansıtmaktadır.

Sosyal geçirgenlik ise, sınır bölgesi ve çevresindeki toplumların kimlikleri ve ilişkilerini ele alan bir kavramdır. Bu çerçevede; sınır bölgesindeki dinsel ve mezhepsel farklılık ve benzerlikler ile, farklı ülke sınırları içerisinde kalınmış olsa da milliyet ve tarihsel köken benzerlikleri, sosyal geçirgenliğin boyutlarını oluşturmaktadır. Diğer yandan sosyal geçirgenliği ölçmeye yönelik yapılacak çalışmalarda, daha detaylı olarak yerel bilgiye (tarihsel ve kültürel köken birliktelikleri, akraba ilişkileri, sınırın diğer tarafından göç edilip edilmediği, diğer taraftaki tarihsel isimlerin korunup korunmadığı vb.) ihtiyaç duyulmaktadır. Ayrıca yerleşmelerde yaşayan nüfus yoğunlukları ve sınıra olan yakınlıkları da sosyal geçirgenliğin olumlu anlamda birer göstergesi olarak ele alınmaktadır.

Ülkeler arası ilişkileri merkezi düzeyde yönlendiren ve geçirgenliğin bir başka boyutu idari geçirgenliktir. Merkezi hükümetlerce belirlenen ve karşı tarafa geçiş kolaylığının en açık göstergesi sayılan vize düzenlemeleri, gümrük kapılarının nitelikleri, çoğunlukla politik yakınlıkla gerçekleştirilen kardeş kent sayıları ve tipleri, ulusal ve daha çok yerel düzeyde ülkeler arasındaki ilişkiler ile birlikte sinırda gerçekleştirilen enformel kaçak geçiş teşebbüsleri, sınırda yakalanan kaçakçılık olay sayıları idari geçirgenliği temsil açısindan değerlendirilmesi gerekli değişkenlerdir.

Diğer üç geçirgenlik türünden bağımsız yanları olan mekânsal geçirgenliğin temel göstergeleri çoğunlukla doğal eşiklerdir. Yüksek eğimli alanlar, fiziki olarak geçişi zorlaştıran doğal engellerin (dere, göl vb.) yanı sıra güvenlik kaygıları ile oluşturulan ve geçişi zorlaştıran yapay eşikler de mekânsal geçirgenliği belirlemektedir. Diğer yandan mekânsal, ekonomik ve politik bağlam çerçevesinde inşa edilen ulaşım altyapısının kalitesi, yerleşimler arası ortalama uzaklık gibi değişkenler de mekânsal geçirgenliğin göstergesi olarak değerlendirilmektedir.

\section{Sosyo-Mekansal İlişkiler A ̆ğ}

Ağ kavramı temelde, insanlar arasındaki karmaşık ilişkiler üzerine kurgulanmış bir metafordur. Ancak nicel yaklaşımların gelişmesiyle birlikte formel hale dönüşmüş ve matematikle ilişkilendirilmiştir (Scott, vd. 2000). Bu çerçe- 
vede ağ analizleri diğer araçlarla karşılaştırıldığında karmaşık sistemleri tanımlayan ve onlarla ilgili hipotezleri test etmeye yarayan yaygın bir yöntem olarak kullanılmaktadır (Hidalgo, 2016). Grafik kuramında ağ; sonlu nokta kümelerinin çizgiler kümesiyle bağlantılı veya yarı bağlantılı olarak oluşturdukları doku olarak tanımlanmaktadır. İlişki ise, sadece iki noktayı bir çizginin birleştirdiği sınırlı ağ şeklindedir (Mitchell, 1969, s.3). Bağlantılar ağların temeli olarak ağlara yapıyı tanımlama kabiliyeti ve aynı zamanda ağdaki noktanın kimliğini tanımlama gücünü sağlamaktadır. Sosyal bilimlere aktarıldığında ise ağlar, kişileri, nesneleri veya olayları birbirine bağlayan belirli bir ilişki biçimi/bağlar (Mitchell, 1969) olarak tanımlanmaktadır.

Sınır bölgelerindeki ilişkiler ağı, sınırın çok boyutluluğu ve karmaşıklığı ile birlikte sosyal, ekonomik, idari ve mekânsal boyutlardaki ilişkilere yönelik veriler ile çok boyutlu değerlendirilmektedir. Sınır bölgesindeki aktörlerin ilişki deseni, oluşan ağın morfolojik özellikleri incelenerek, ağın etkileşim boyutu ve sınır bölgelerinin ilişkisel karakterleri ortaya konabilmektedir. Sosyal ağ analizi ile sınır ötesi kentlerin kimliklerine ilişkin kestirimde bulunulabilmekte, sınır kentlerinin ağdaki merkeziliği, arasındalığı, karşıllıklılığı, geçirgenliği ve yoğunluğu test edilebilmektedir.

\section{Sınır Bölgelerinde Yönetişim}

Küreselleşme ile ilişkili gelişmelerde ulus devletlerde egemenlik, bölge, kimlik ve sınır konuları öne çıkmaktadır. Sınırlardaki ekonomik, politik, sosyal ve kültürel süreçler gün geçtikçe ulus devletlerin bakş̧ açları ile örtüşmemeye başlamış (Popescu, 2006) ve bu çatışma, ortak yönetişim arayışlarını gündeme getirmiştir. Yönetişim kuramının devlet ve piyasa mekanizmasına alternatif olarak ortaya çıkmış olması, sınır bölgesi için uygulanacak yönetişimi de kolaylaştırmaktadır. Rhodes (2007) ulusal çerçevede yönetişimi, hükümetin anlamının değişimi ve farklı bir yönetim sürecinin gündeme gelmesi olarak tanımlanmıştır. Yönetişimin birbirini etkileyen aktörlerin etkileşimini içeren yapısı, kamu ve özel sektör arasındaki sınırın yumuşatılmasına sebep olmaktadır. Sınır bölgelerinde yönetişim; temelde iki farklı bakış açısı ile ele alınmaktadır. Bunlardan ilki; alan üzerinden, ulusal aktörlerin yürütücülüğünde federal idari sistemlerde hayata geçirilen yönetişim türüdür. İkincisi ise; farklı düzey ve sektörlerdeki aktörleri içeren, seçmeci ve farklı ölçeklerde hayata geçebilen fonksiyonel yönetişimdir (Blatter, 2004). Bu yaklaşımlar s1nır bölgelerini çeperde kabul edip, merkezden çeperi tanımlamaktadır. Buradaki temel kısıt, sınırı küresel değişimlere paralel olacak şekilde fonksiyonel 
olarak değerlendiren ve merkeze koyan bir yaklaşımın geliştirilememiş olmasıdır. Jessop vd. (2008) sınır ötesi yönetişimi, içerdiği işbirliği, karşlllık ve dayanışma kavramları ile "öze dönüşlü bir örgütlenme" (reflexive self-organization) olarak dar anlamda tanımlanmıştır. Tekeli (2004) yöneten ve yönetilen ikililiğini ortadan kaldırma iddiasının yönetişimi bir demokrasi türevi haline getirdiğini savunmaktadır. Bu bağlamda sınır bölgelerinde, demokrasi tanımında tam olarak içerilmeyen, ağ yönetişimi çerçevesinde ortaya çıkan bir yönetişim türü tartışması ortaya çıkmaktadır.

Sınır ötesi yönetişim, ulusüstü olmasından dolayı daha karmaşık bir yapıda ve farklı normlar ile ağsal ilişki içerisinde bir kavram olarak karşımıza çıkmaktadır. Bu yeni biçim, sınırın bulanık işlevleri ile şekillenmekte ve bu süreçte uygulamada ortaya çıkan sorunlar ile birlikte yeniden tanımlanan bir süreç olarak ilerlemektedir. Bu anlamda sınır bölgelerinde yönetişimin önünde kırılgan bir yapı mevcuttur. Bu yapı, sınır bölgeleri için kurgulanacak yönetişim modelinin ana omurgasını belirlemektedir. Bu yapı çerçevesinde, yönetişimin devlet sınırlarının ötesinde kavramsallaştırmasında çeşitli prensiplere göre yeniden tasarlanması gerektiğini savunan ve "yönetişimin yönetişimi" (Kooiman ve Jentoft, 2009) olarak adlandırılan üst-yönetişim (meta-governance) kavramı ortaya atılmaktadır. Yönetişimin epistemolojisine yönelik bir üst-kuram olan üst-yönetişim; değerler, normlar ve prensiplerin yönetişim sistemlerini ve yönetişim yaklaşımlarını nasıl desteklediğine ilişkin sorular sormaktadır. Bununla birlikte, ulus devlet dışında da farklı aktörlerin (hükümetler, bölgesel otoriteler) dengeli ve koordineli bir şekilde, yerindenlik ilkesi çerçevesinde, sistematik bir bütünleşme ve katılımını ifade eden "çok düzlemli yönetişim" (multi-level governance) (European Comission, 2011, s.85) kavramı ise; $A B$ bölgesel uyum sürecinde mekânsal plancılar tarafından "çok katmanlı bölgesel yönetişim" olarak tanımlanmıştır. Çok katmanlı yönetişim, kamu politikalarında karar alma sürecinde bir yandan devlet, özel kesim ve sivil toplum kuruluşlarının oluşturduğu çoğulcu bir yapıya; öte yandan, ulus-üstü, ulusal, ulus-altı kademeler arasındaki hiyerarşinin kalkmasına işaret etmektedir.

Bu çalışma, sınır bölgelerindeki sosyo-mekânsal etkileşim ve yönetişimin ortaya konulmasında, öncelikle ulus devletlerarası geçirgenliğin ölçülmesine yönelik bütüncül bir yaklaşım geliştirilmesini; ardından sınır üzerinden gerçekleşen ve devletlerarasında oluşan çok boyutlu akımlar ile oluşan ağ yapısının yerleşmelerin ağsal ilişkileri çerçevesinde analiz edilmesini ve sınır bölgesinin özgünlükleri çerçevesinde bir yönetişim çerçevesi sunulmasını amaçlamaktadır. Bu kapsamda çalışmada öncelikle teorik olarak sınır geçirgenliği 
kavramı sosyo-mekânsal olarak tanımlanmış ve oluşturulan parametreler çerçevesinde ulusal sınırlarda Çok Değişkenli Sınır Geçirgenlik Endeksi (ÇDSGE) elde edilmiştir. Elde edilen endeks çerçevesinde sınır geçirgenliğinin orta ve yüksek olduğu sınır bölgelerinde yerel düzeydeki akımlar ile oluşan ağ yapıları, makro ve mikro düzeyde ağ metrikleri ile analiz edilmiştir. Bu kapsamda yerel düzeyde çok boyutlu akımlar ile oluşan ağ yapısı, yerleşmelerin sınırın ötesi ile kurdukları ilişkiler çerçevesinde oluşan ilişkisel coğrafyayı ortaya çıkarmıştır. Çalışmanın üçüncü aşamasında sınır bölgelerinin özgünlükleri çerçevesinde bir yönetişim çerçevesi tanımlanmıştır. Yüksek ve orta geçirgenliğe sahip sınır bölgeleri için ortaya atılan ortak yönetişim çerçevesi bu tanımlamanın omurgasını oluşturmaktadır. Bu çerçevede Şekil 2'de sınır geçirgenliğin belirlenmesi ve akımlar ile oluşan ağ yapıları değerlendirilerek, yeni bir yönetişim yaklaşımının ortaya konulmasına yönelik yöntemsel çerçevesi verilmektedir.

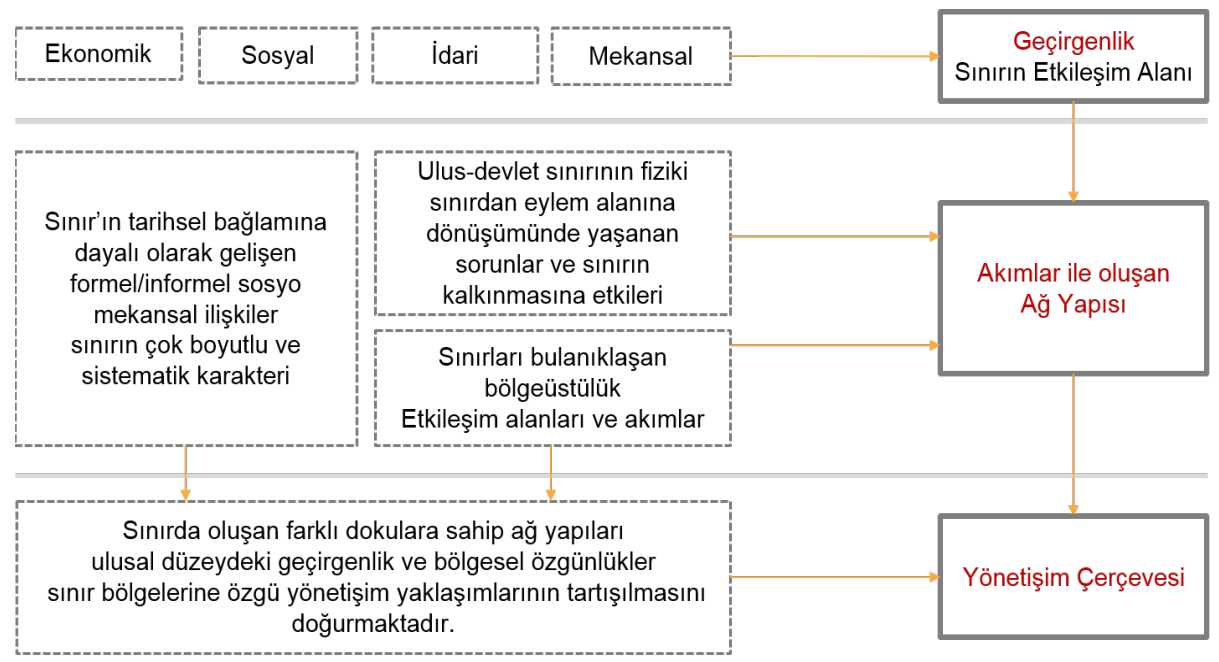

Şekil 2. Çalışmanın sınır ve sınır ötesi ilişkileri ele alış biçimi

\section{Yöntem}

Sınır bölgelerindeki ilişkiler ağı, ulus devletlerin çizdiği katî sınırların ötesinde daha fazla çaba isteyen kolektif bir algilama gerektirmektedir. Bu çalışmada sınırın çok boyutluluğu ve karmaşıklığı, sınır bölgelerinde merkezi ve yerel düzeyde toplanan sosyal, ekonomik, idari ve mekânsal boyutlardaki veriler ve yerel düzeyde gerçekleştirilen görüşmeler ve anketlerin analizi ile 
değerlendirilmektedir. Bu çerçevede çalışmada izlenen yöntem, birbiri ile bağlantılı üç aşamadan oluşturulmuştur.

Çalışmada ilk aşamada; Çok Değişkenli Sınır Geçirgenlik Endeksi (ÇDSGE) olarak tanımlanan endeks çalışması geliştirilmiştir. ÇDSGE, şimdiye kadar farklı disiplinlerce tekil olarak ele alınan sınırdaki geçirgenliği, ekonomik, sosyal, idari ve mekânsal göstergeler ile çok boyutlu olarak inşa ederek, ulus devletlerin sınırlarındaki geçirgenliğini ölçmeye yönelik bir yöntem önerisi getirmektedir. Söz konusu endeks, sınırlar arası ilişki düzeylerinin çeşitli belirleyiciler ve öncelikler üzerine kurulduğundan yola çıarak, çalışma kapsamında yapılan tanım çerçevesinde ekonomik, sosyal, idari ve mekânsal düzenlemeler çerçevesinde oluşturulan göstergeler ile oluşturulmaktadır.

ÇDSGE olarak tanımlanan kavramı elde etmek için öncelikle ekonomik, sosyal, idari/yönetsel ve mekânsal boyutlarda değişken türleri belirlenmiştir. Ülke düzeyinde her bir boyutta (ekonomik, sosyal, idari/yönetsel ve mekânsal) merkezi kurum ve kuruluşlardan 2013-2014 yıllarına ait veriler ülke, bölge, il ve sınır kapısı boyutları ile zaman, kapsam, tiplerine göre analize konu edilmiştir. Belirlenen gösterge değişkenlere yönelik tekrarı engellemek için yüksek korelasyona sahip değişkenler dışarıda bırakılmıştır. ÇDSGE'nin oluşturulmasında toplam 22 adet değişken kullanılmıştır.

ÇDSGE açısından en önemli aşamalardan olan değişkenlerin coğrafi boyuta taşınması aşaması olduğundan, değişkenler öncelikle nokta, çizgi, çoklu çizgi olarak sınıflandırılmıştır. ÇDSGE için geliştirilen göstergeler farklı düzlemlerde olduğu için öncelikle tüm değişkenler mekânsal düzleme uyarlanmıştır. Bu uyarlama, ekonomik gösterge değişkenlerinin il sınırı, ülke sınırı, gümrük kapısı; sosyal gösterge değişkenlerinin il sınırı, ülke sınırı ve idari gösterge değişkenlerinin ülke sınırı şekline dönüştürülmesi ile yapılmıştır. Mekânsal olarak elde edilen değişkenler ise yapılan mekânsal analizler ile coğrafi veri tabanına aktarılmıştır. Ülke düzeyinde elde edilen ekonomik değişkenler yönlerine göre değil, geçirgenlik açısından tüm sistem içerisindeki skalar düzeyin belirlenmesi açısından hacimsel verilere dönüştürülerek hesaplamalara katılmıştır. Bu sayede ekonomik eksende ülke düzeyinde geçirgenliğin belirleyicisi olabilecek gösterge setleri oluşturulmuştur.

Coğrafi boyutta resim (raster) hesaplamaları yapabilmek için, tüm ülke kara sınırları hattı 10x10 km boyutunda raster formatına dönüştürülmüştür. Değişkenlerin aynı birimde olmamaları ve diğer değişkenlerin endeks puanına daha fazla etki etmemesi için ilk oluşturulan haritalar ayrıca normalleştirilmiş ve standartlaştırılmıştır. Veri tipi ve çalışmanın amacı doğrultusunda 
uygun normalleştirme algoritması (bulanık küme üyelik fonksiyonları) seçimi yapılmıştır. Bu noktada hangi bulanık küme üyelik fonksiyonunun kullanılacağına karar verilmesi gerekmektedir. Bu çerçevede hesaplanan veriler bulanık üyelik fonksiyonları kullanılarak 0-1 arasına standartlaştırılmıştır. Bileşenler arası negatif pozitif ilişkiler belirlenerek ilgili bulanık fonksiyona ilişkin hesaplamalar yapılmıştır. Ardından her bir boyut (ekonomik, sosyal, idari/yönetsel ve mekânsal) için 10x10 km'lik 1zgaralarda resim (raster) hesaplamaları yapılarak ilgili boyutun geçirgenliği hesaplanmıştır. Bu noktada her bir eksen için ilgili ağırlıklandırma metodları kullanılarak basit ağırlıklandırma ile raster hesaplamaları yapılmış her bir eksene ait alt endeks değerleri elde edilmiştir ve her bir değişkene eşit önem verilerek endeks oluşturulmuştur.

ÇDSGE endeksinden yola çıkılarak, geçirgenlik dereceleri ve sınır bölgelerindeki güvenlik koşulları çerçevesinde geçirgenlik düzeyi orta ve yüksek olan Türkiye-AB (Yunanistan ve Bulgaristan) ve Türkiye-Gürcistan Sınır Bölgeleri alan araştırması yapılmak üzere seçilmiştir (Şekil 3).

İkinci aşamada, geçirgenlik analizi sonuçlarına göre belirlenen yüksek ve orta düzeydeki geçirgenliğe sahip bu iki sınır bölgesinde alan araştırması yapılmış ve merkezi düzeyde elde edilen verilerin ötesinde, yönetişim sürecinde önemli rol oynayan yerleşimler arası sosyal ağlar, enformel ilişki ağları ve sınır ötesi etkileşim düzeylerine yönelik veriler elde edilmiştir. Bu süreç, ilgili yerel aktörlerle (kamu kurum/kuruluş teşkilatları, kalkınma ajansları, belediyeler, sivil toplum örgütleri, muhtarlar, vb.) yapılan derinlemesine görüşmeleri ve bu görüşmelerden elde edilen bilgileri içermektedir. Yerel düzeydeki alan araştırmasının ikinci kısmı, sınır bölgesi olarak tanımlanan, s1nırın Türkiye tarafı ve diğer tarafında ilk $100 \mathrm{~km}$ de sınır ötesi ile işbirliği bulunan yaşayanlara uygulanmak üzere sınır kapılarında yapılan ve toplamda 800 kişiyle gerçekleştirilen anket çalışmasıdır (Şekil 3). Bu çerçevede hem derinlemesine görüşmeler hem de anketler ile sınırın her iki tarafında ekonomik, sosyal, yönetsel ve mekânsal ilişkiler hakkında bilgi toplanmıştır. Böylece, iki sınır bölgesinde sosyal ağ analizi yöntemleri ile sınır bölgelerindeki sosyo-mekansal etkileşimler değerlendirilmiş, sınır bölgelerindeki sosyal ve enformel etkileşim düzeyleri karşılaştırmalı olarak analiz edilmiştir. 


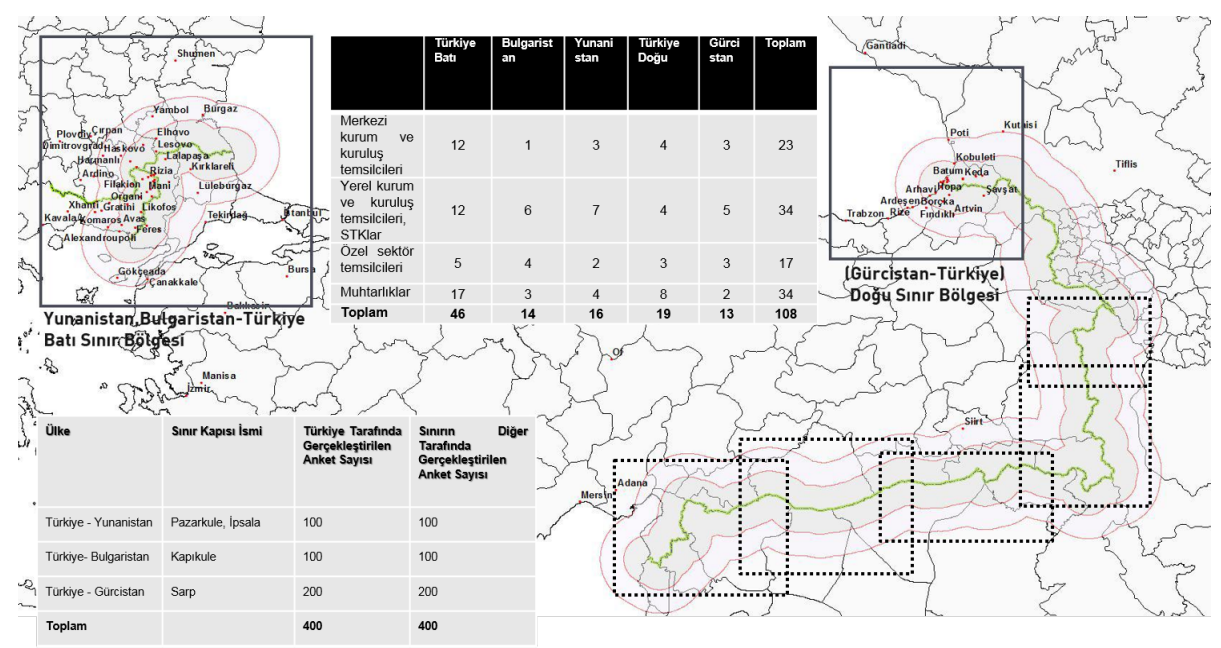

Şekil 3. Çalışma Alanı

Üçüncü aşamada ise; birinci ve ikinci aşamada yapılan analizler neticesinde oluşturulan endeks ve uygulanan yöntemsel yaklaşımlar çerçevesinde, bölgelere ve etkileşimde olduğu ülkelere özgü farklılıklar taşıyan, sınır bölgeleri için bir yönetişim çerçevesi geliştirilmiştir.

\section{Türkiye Stnır Bölgelerindeki Sosyo-Mekânsal Etkileşim ve Yönetişim} Geçirgenlik Endeksi

Ekonomik, sosyal, idari ve mekânsal geçirgenlik olmak üzere dört ayr1 başlık altında belirlenen göstergeler ile değerlendirilen ÇDSGE için her bir katmanda veriler toplanarak 10x10 kilometrekarelik büyüklüklere çevrilerek raster hesaplamaları yapılmıştır. Ülke düzeyinde toplanan 22 adet değişken ile oluşturulan katmanlarda sınır hattı boyunca her iki taraftan 50 şer kilometrelik bir alanda analizler gerçekleştirilmiştir. Çok değişkenli sınır geçirgenlik endeksinin merkezi verilere dayanarak oluşturulduğu bu çalışma ile sınır geçirgenliği tanımı yeniden yapılarak 22 adet değişkene bağlı geçirgenlik düzeyleri Türkiye sınırlarında test edilmiştir. Şekil 4'de seçilen 20 değişken için gerçekleştirilen analiz sonuçları verilmektedir. 


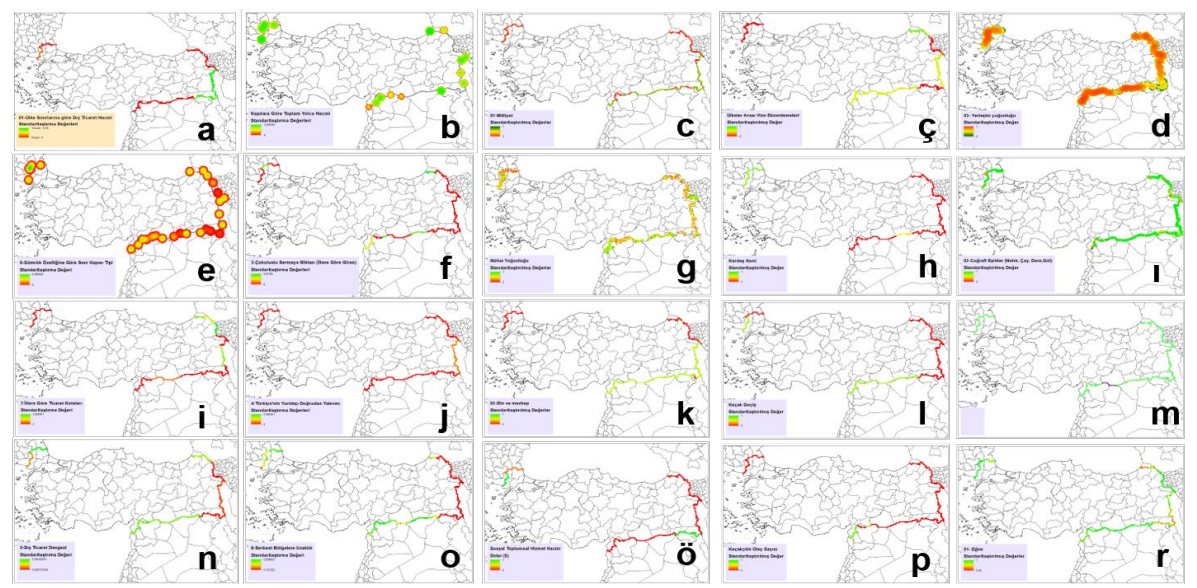

Şekil 4. a) Ülkelere göre ticaret hacmi (\$) b) Kapılara göre toplam yolcu hacmi (kişi) c) Milliyetlerine göre coğrafya komşuluğu ç) Vize düzenlemeleri d) Yerleşim Yoğunluğu e) Gümrük özelliğine göre sınır kapısı tipi f) Illere göre giren çok uluslu sermaye miktarı (\$) g) Nüfus yoğunluğu (km²/kişi) h) Kardeş kent sayısı 1) Coğrafi eşikler (nehir, çay, dere, göl) i) İllere göre ticaret kotaları (TL) j) Türkiye'nin sınır bölgesinde yurtdışı doğrudan yatırımları k) Din ve mezheplerine göre coğrafya komşuluğu 1) Kaçak geçiş teşebbüsü m) Sınır çizen yapay eşikler n) Dış ticaret dengesi (\$) o) Serbest ticaret bölgelerine uzaklık (km) ö) Sosyal ve toplumsal nitelikli ticaret hacmi p) Sınır ilinde yakalanan kaçakçılık olay sayısı

ÇDSGE'yi oluşturan her bir değişkene ait değerlerin toplanması ile elde edilen ızgaralar 0 ile 1 arasında değerler alabilmektedir. Bu çerçevede çalışmanın sonuçlarını basitleştirerek sunmak adına üç adet geçirgenlik düzeyi tanımlanarak az geçirgen, geçirgen ve çok geçirgen olarak bir sınıflandırma yapılmıştır. 22 değişkenin tamamından en yüksek 1 değeri alındığı düşünüldüğünde, toplam geçirgenliğin en yüksek düzeyde 1 olabileceği anlaşılmaktadır. Analizler sonucunda tanımlanan 10x10 km'lik alanda toplam 22 değişkenin her birinden alınan farklı değerler neticesinde en geçirgen 1zgara, 0,47 geçirgenlik değeri ile Gaziantep/Suriye sınırında yer almaktadır. En az geçirgen ızgara ise 0,04 geçirgenlik değeri ile Kırklareli/Bulgaristan sınırında gerçekleşmiştir. 


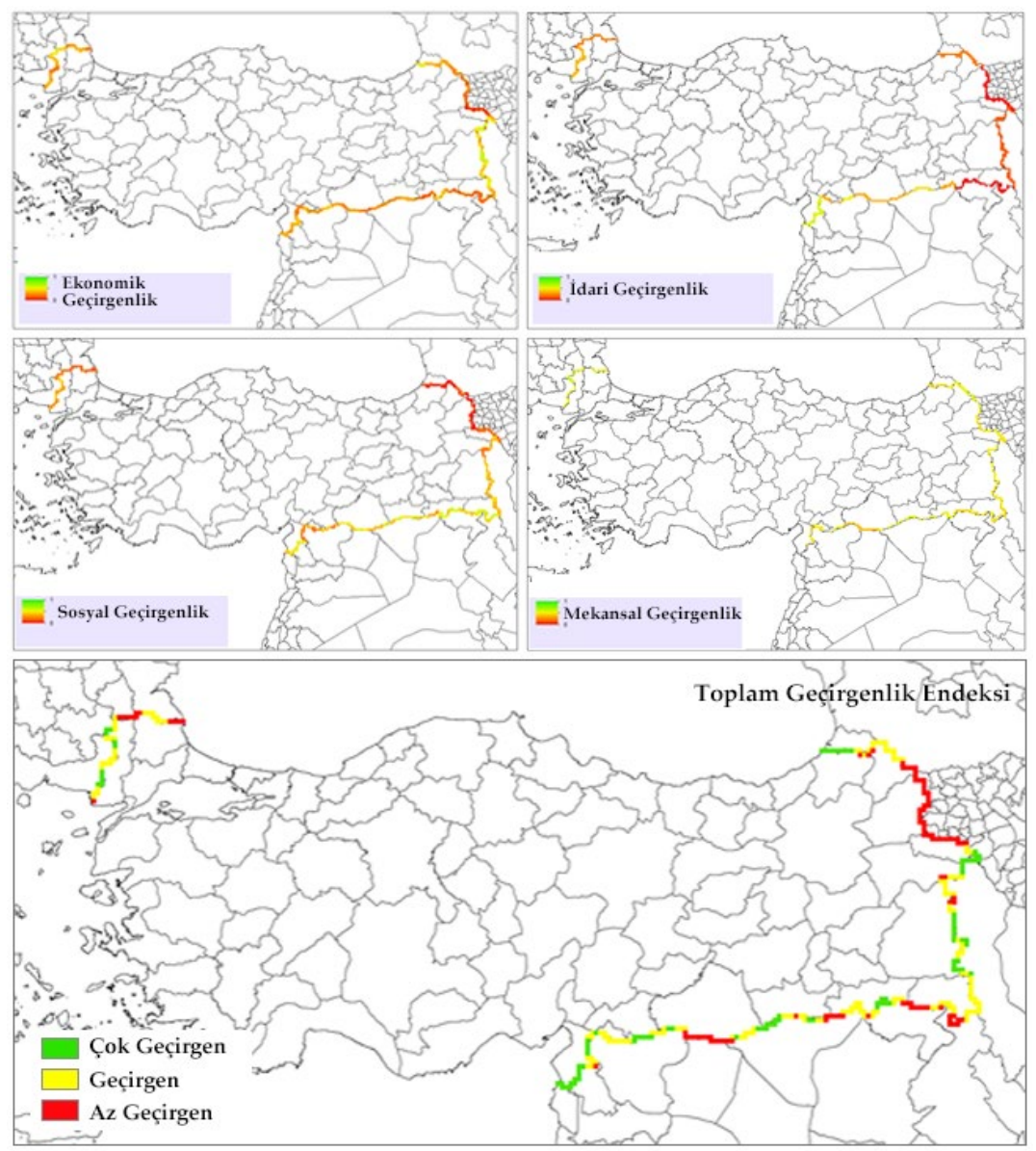

Şekil 5. Türkiye çok değişkenli sınır geçirgenlik endeksi

Şekil 5'te Türkiye kara sınırları üzerinden elde edilen ekonomik, sosyal, idari ve mekânsal geçirgenlik endeksleri ile tüm boyutlardan toplamda elde edilen geçirgenlik endeksi sunulmaktadır. Ekonomik geçirgenlik endeksi çerçevesinde Van, Edirne ve Artvin il sınırları ve buralardaki hudut kapılarındaki geçirgenlik seviyesi yüksek çıkarken, sınır kapılarının etkin olmadığı, ekonomik ilişkilerin düşük seviyede seyrettiği ülke sınırlarındaki geçirgenlik değerleri düşük çımaktadır. Ülke olarak İran, Gürcistan ve Bulgaristan ile yüksek ekonomik geçirgenliğe sahip bir ilişki seviyesi saptanırken, Ermenistan ile sınırların kapalı olması sebebiyle sınır hattında düşük geçirgenlik öne çıkmaktadır. 
Ermenistan ile sınır hattı boyunca düşük sosyal geçirgenlik seviyesinin belirgin olarak gözlenmesi sosyal geçirgenlikte de ekonomik geçirgenlikte olduğu gibi bütüncül bir politik arka planın geçirgenlik üzerinde etkili olduğunu doğrulamaktadır. Diğer yandan Gürcistan ve Bulgaristan tarafındaki yerleşme nüfuslarının düşük olması, bu bölgelere ait sosyal geçirgenliğin daha düşük çıkmasında öne çıan bir durumdur. Sosyal geçirgenliğin ülke sınırları boyunca aynı karakteri yansıtması il ve sınır kapısı düzeyinde sosyal olarak sınır geçirgenliğini ölçecek göstergelerin bulunmamasından kaynaklanmaktadır.

Ülkelerin kendi çıkarlarını koruma önceliğiyle oluşturdukları politik kararlar sınırların geçirgenliğini etkileyebilmektedir. Sınırı korumak ve geçiş rejimini belirlemek üzere geliş̧irilen politikalar neticesinde geçirgenliği yansitma düzeyi yüksek olan göstergeler belirlenmiştir. Yönetsel ilişkiler düzeyinde Suriye, Bulgaristan ve Yunanistan daha fazla geçirgenliğe sahip ülkeler olarak öne çıkmaktadır. Diğer yandan Ermenistan ve Irak daha az geçirgen iken, İran ve Gürcistan ise bunlardan görece daha fazla geçirgenliğe sahiptir.

Mekânsal geçirgenlik diğer geçirgenlik türlerine göre daha somut olarak değerlendirilebilen ve üzerinde daha çok çalışma yapılmış bir alandır. Bu çalişmada mekânsal geçirgenlik göstergeleri doğal ve doğal olmayan eşikler, altyapının durumu ve yerleşmeler açısından ele alınarak değerlendirmeler yapılmıştır. Mekânsal geçirgenlik göstergeleri altında; eğim, doğal eşikler, yerleşim sıklığı, karayolu ve demiryolu ulaşım altyapısı ve sınır çizen yapay eşik verileri kullanılarak elde edilmiştir. Ülke sınırlarının tamamı değerlendirildiğinde en geçirgen sınır boyu sırasıyla Suriye, İran, Irak, Gürcistan, Yunanistan, Ermenistan, Bulgaristan ve Nahcivan sınırları olarak ortaya çımaktadır. Suriye ile geçirgenliğin yüksek çıkması uzun sınır hattı ve fiziki engellerin çok az olması ve mayınlı arazi dışında diğer tüm göstergelerin geçirgenliği olumlu yönde etkilediği bir sınır hattı olmasından kaynaklanmaktadır. Nahçivan ile düşük çıkmasının nedeni ise Nahçivan-Türkiye sınır hattının tek bir ızgaraya sığmasından kaynaklanmaktadır.

Sınır geçirgenlik endeksi sonucunda geçirgenliği orta ve yüksek olarak ortaya çıan iki sınır bölgesi olan Türkiye-AB (Bulgaristan ve Yunanistan) ve Türkiye-Gürcistan sınır bölgelerindeki sosyo-mekânsal etkileşimi araştırmak ve analiz etmek üzere alan araştırması yapılacak bölgeler olarak seçilmiştir. Türkiye AB sınırını oluşturan Türkiye-Bulgaristan, Türkiye-Yunanistan ve kuzeydoğu sınırını oluşturan Türkiye-Gürcistan sınırları politik ve idari ör- 
gütlenmeleri, kültürel, sosyal, ekonomik, tarihsel süreçleri ve benzeri konularda önemli farklılıklar göstermektedir. Bu çerçevede Tablo 1'de iki sınır bölgesinin genel özellikleri ve ortalama geçirgenlik düzeyleri yer almaktadır.

Tablo 1. AB ve Gürcistan Sınır Bölgeleri Özellikleri

\begin{tabular}{lll}
\hline & AB Sınır Bölgesi & Gürcistan Sınır Bölgesi \\
\hline Komşu Ülkeler & Yunanistan, Bulgaristan & Gürcistan \\
\hline Aktif Sınır Kapıları & $\begin{array}{l}\text { Pazarkule, İpsala, Kapıkule } \\
\text { Hamzabeyli, Dereköy }\end{array}$ & $\begin{array}{l}\text { Sarp } \\
\text { Posof-Türkgözü }\end{array}$ \\
\hline Sınır Uzunluğu $(\mathrm{km})$ & $465 \mathrm{~km}$ & $252 \mathrm{~km}$ \\
\hline $\begin{array}{l}\text { Sınırdan itibaren ilk } 100 \mathrm{~km} \text { lik } \\
\text { hatta yaşayan nüfus }\end{array}$ & 1.250 .000 & 550.000 \\
\hline $\begin{array}{l}\text { Ülke Düzeyi Sınır } \\
\text { Geçirgenlik Ortalamaları }\end{array}$ & 0,23 & 0,27 \\
\hline Yerleşme Morfolojisi & $\begin{array}{l}\text { Düz ve engebeli arazide } \\
\text { dağınık yerleşme deseni }\end{array}$ & $\begin{array}{l}\text { Sahil şeridine paralel } \\
\text { yerleşme deseni }\end{array}$ \\
\hline
\end{tabular}

Alan araştırmasından elde edilen veriler sosyal ağ analizleri ve çok boyutlu parametreler yardımıyla sosyo-mekansal etkileşimi tanımlamada kullanılmış ve sınır bölgelerinde yönetişim yaklaşımına altlık oluşturmuştur.

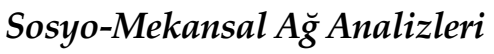

Çalışma çerçevesinde sınır bölgeleri çok merkezli ağ yapılarından oluşan sosyo-mekânsal etkileşimin mekânı olarak tanımlanmaktadır. Analizlerde, sınır yerleşmelerinde ikamet eden ve sınırın diğer tarafına geçenler bileşen, bu bileşenlerin sınırın diğer tarafı ile kurdukları bağ ise ilişki olarak ele alınmıştır. Buradaki ilişki tek boyutlu bir ilişkiden çok, yerleşimler arası akımın taşıdığı sosyal, ekonomik, idari ve mekânsal özellikleri bulunan çok boyutlu bir ilişkiye denk gelmektedir. Sosyal ağ analizi kavramları kullanılarak yapılan analizlerde oluşan ağın genel özelliklerinin yanı sıra bileşen düzeyindeki ilişkiler de analiz edilmiştir. Sınırda gerçekleştirilen anketler ile elde edilen geliş noktası, gidiş noktası, konum ve koordinatlar, sınıra olan mesafe vb. veriler ile (i) makro düzey ağ analizleri (düğüm ve bağlar, kümelenme, derece, ağırlıklı derece ve ağ çapı) (ii) mikro düzey ağ analizleri (yakınlık, derece, arasindalık merkeziliği (Freeman, 1978) ve özvektör merkeziliği (Bonacich, 1972) ve (iii) ağ dokusu analizleri olmak üzere üç düzeyde ağ analizi ortaya konmuştur.

Makro düzeyde yapılan ağ analizleri ile ağın geneline ilişkin olarak dügümler, bileşenler arası kurulan bağlar, benzer nitelikli oluşan kümeler ile ağın derece sayısı ve çapının elde edilmesi önem kazanmaktadır. Buna göre 
ağın bileşenleri arasında kurulan ilişki sayısını ifade eden derece kavramı, yönlü ilişkilerden oluşan ağlarda giden ve gelen bağlar olarak ölçülebilmektedir (Opsahl vd., 2010). Bir bileşenin bağlantı sayısını gösteren derecenin artması o bileşen için daha fazla seçenek olasılı̆̆ını göstermektedir. Ağırlıklı derece ise bileşenlerin birbirleri ile kurduğu ilişkilerin toplamıdır. Ağdaki bileşenlerden birbirine en uzak bireylerin uzaklığı ağın çapını vermektedir. Sınır bölgesinde kurulan ağlar özelinde ağırlıklı derece bir yerleşimin kurduğu ilişki düzeyini verirken ağırlıklı ortalama derece ise yerleşmeler arası kurulan ilişkilerin toplamları üzerinden alınan ortalamayı vermektedir.

Mikro düzeyde, ağdaki bileşenlerin konum ve ilişkileri ile ortaya çıkan sosyal ağ yapısının analiz edilmesinde kullanılan merkezilik ölçümleri (Valente, 1997) kullanılmaktadır. Mikro düzey ağ analizleri ile bileşenin konumunu diğer bileşenlere göre analiz ederek çeşitli algoritmalar ile ağın homojenliğine, coğrafi konumuna, ulaşılabilirliğine, diğer bileşenlere kolay ulaşılmasına, konumu sebebiyle diğer komşu bileşenleri etkileme vb. gibi ilişkiselliğine ilişkin ipucu elde edilebilmektedir (Borgatti, 2005). İlişki sayıları (birincil), ilişki yönü (dışarı ve içeri merkezilik), ayrıksılığı (eccentricity) merkezilik ölçümleri sınır yerleşmelerinin ilişkisel yapılarını ortaya koymaktadır (Scott, 2000). Sınır bölgesi ilişkiler analizi için merkezilik ölçümleri yerleşmenin konumuna bakılmaksızın ilişkiler ağı dikkate alındığında ortaya çıkan ölçümlerdir. Böylelikle ağ içindeki bir yerleşmenin konumundan bağımsız olarak ulaşlabilirliği ve bunun konumu ile korelasyonu test edilmiştir.

Ağdaki anonim ilişkilerin yapısını analiz ederek ağın ilişkisel dokusunu ortaya koyan ve istatistiksel olarak anlamlı frekansların oluşturduğu doku olarak tanımlanan ağ dokusu (Milo vd. 2002), ağdaki farklı tür ve sayıdaki rastgele oluşabilecek bağların hesaplanması ile tespit edilmektedir (Shen-Orr S vd. 2002). Ağ dokularının tespitinde öncelikle farklı tipteki motifler sayılmakta, uçların dereceleri korunarak rastgelelikleri sağlanmakta, rastgeleliği sağlanan ağdaki motiflerin frekansları hesaplanmaktadır. Bu çerçevede elde edilen ağ dokusu sınır bölgesindeki yönetişimin çerçevesini çizecek önemli bir argümandır.

Çalışma kapsamında seçilen sınır bölgeleri arasındaki temel yapıyı ortaya çıkarmak ve farklılıkları tespit etmek üzere üç farklı ağ yapısı analiz edilmiştir. Bunlardan ilki Türkiye ile $\mathrm{AB}$ arasında olan Türkiye-Bulgaristan ve Türkiye-Yunanistan sınırlarının yer aldığı Batı Sınır Bölgesini kapsayan ağ, ikincisi ise Türkiye-Gürcistan sınırının yer aldığı Doğu Sınır Bölgesini kapsayan ağ ve üçüncüsü ise Batı ve Doğu sınır bölgelerini kapsayan tüm ağdır. 
Ele alınan üç farklı ağda, sınır bölgesi etkileşiminde yer alan ve sınırın diğer tarafı ile ilişkili olan yerleşmeler bileşenler olarak değerlendirilmiştir. Buna göre Türkiye-Avrupa Birliği ağında toplam 69 bileşen 98 adet bağ, Türkiye-Gürcistan ağında toplam 48 bileşen 66 adet bağ, tüm ağ ele alındığında ise; toplamda 117 bileşen 164 adet yönlü ilişki içerisinde yer alarak ağırlıklı bir ağ yapısı meydana getirmektedir. Sosyal ağın içindeki var olan ilişki sayısının olası tüm ilişki sayısına oranı ağın yoğunluk değerini vermektedir. 0 ile 1 arasında değişen bu değer çalışmanın kapsamı ve ağın türünden dolayı $0^{\prime} a$ yakın değerler almıştır. Buna göre ele alınan üç ağın yoğunlukları TürkiyeAB $(0,020)$, Türkiye-Gürcistan $(0,029)$ ve tüm ağ ise $(0,012)$ olarak hesaplanmıştır. Bu durum, sınır bölgelerinde diğer tarafa geçişler üzerinden kurgulanan ağ yapılarının ülke içindeki yerleşimler arası bağları göz ardı ettiğinden daha seyrek çıkması olarak yorumlanmaktadır. Ancak bu değerin aynı şartlarda toplanan veriler ile farklı bölgeler için kıyaslanması sınır bölgelerindeki ilişki yoğunluğuna ilişkin önemli ipuçları vermektedir.

Türkiye-Gürcistan sinur bölgesinde ağ yoğunluğunun görece fazla olması daha az yerleşmenin daha fazla etkileşime girdiği sonucunu doğurmaktadır. Ağın bileşenleri arasında kurulan ilişki sayısını ifade eden derece kavramı yönlü ilişkilerden oluşan ağlarda giden ve gelen bağlar olarak ölçülebilmektedir (Opsahl vd., 2010). Bir bileşenin bağlantı sayısını gösteren derecenin artması o bileşen için daha fazla seçenek olasılığını göstermektedir. Ağırlıklı derece ise bileşenlerin birbirleri ile kurduğu ilişkilerin toplamıdır. Ağdaki bileşenlerden birbirine en uzak bireylerin uzaklığı ağın çapını vermektedir. Sınır bölgesinde kurulan ağlar özelinde ağırlıklı derece bir yerleşimin kurduğu ilişki düzeyini verirken ağırlıklı ortalama derece ise yerleşmeler arası kurulan ilişkilerin toplamları üzerinden alınan ortalamayı vermektedir. Sınır bölgesi özelinde ağırlıklı ortalama derecenin görece yüksek olduğu Türkiye-Gürcistan arasındaki yerleşmeler arası ilişki düzeyi Türkiye-Trakya Bölgesi arasındakine göre daha yüksektir.

Makro ve mikro analiz sonuçları sınır bölgesinde oluşan ağın yapısal özelliklerine (merkezilik, karşılıklılık, simetriklik, geçişkenlik vb.) ilişkin bazı çkarımlar yapılmasına olanak sağlamaktadır. Diğer yandan nüfus, sınıra olan uzaklık, altyapı, sosyo-kültürel ilişkiler ve günlük ekonomik ilişkiler bu bulguları etkileyen temel parametrelerdir. Batı ve Doğu sınır bölgelerini içine alan tüm ağ "merkezilikler" açısından değerlendirildiğinde (Şekil 6) her bir merkeziliğin tanımı uyarınca farklı ağırlıklı gösterimler elde edilmiştir. 


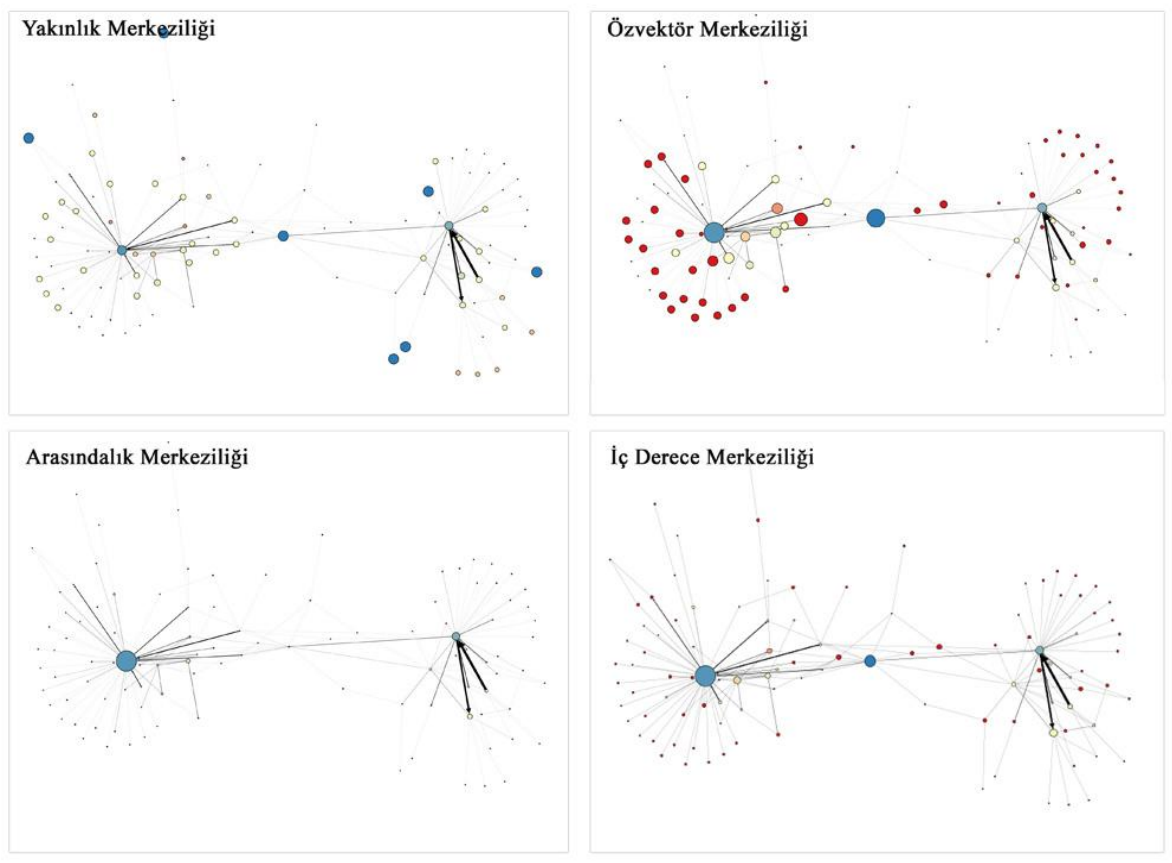

Şekil 6. Tüm Ağın Merkezilik Değerlerinin Karşılaştırılması

Buna göre sadece doğrudan bağların dikkate alındığı iç derece merkeziliğinde sırasıyla Edirne, İstanbul ve Batum yerleşmeleri ağda merkezi bir konumda yer almaktadır. Bu merkezilik türü sınır bölgesi çerçevesinden değerlendirildiğinde en fazla yönlü bağı üzerinde toplayan veya doğrudan en fazla gelinen yerleşim yerini göstermesi açısından önemli görülmektedir. Ağı bir bütün olarak ele aldığımızda iç derece merkeziliği yüksek olan yerleşimlerin ikisi Türkiye tarafında diğer ise Gürcistan tarafında çıkmaktadır. Komşu bileşenleri de dikkate alan yakınlık merkeziliğine göre komşu bileşenlerden daha merkezi olanları hesaplamaya katan özvektör merkeziliğinde yerleşmeler arasındaki merkezilik hiyerarşisi daha net olarak ortaya çıkmaktadır. Burada İstanbul her iki sınır bölgesinden de bağlar ve ilişkiler içermesi açısından ön plana çıkmaktadır. Arasındalık merkeziliği değerleri ise ağdaki yerleşmenin köprü olabilme özelliğini ortaya çıkarması açısından önemlidir.

Çalışma kapsamında ele alınan sınır bölgeleri ve tüm ağdaki ağ dokusunun analizinde Alon (2007) tarafından geliştirilen ve ağdaki baskın dokuları ortaya koyan DOS ortamında çalışan "Mfinder 1.2" programı kullanılmıştır. 
Buna göre her üç ağ için 3 ve 4 bileşenli ağ dokuları ortaya çıkarılarak dokunun merkezilik, geçişkenlik ve karşılıklılık yapısına ilişkin değerlendirmeler yapılmıştır (Şekil 7).

\begin{tabular}{|c|c|c|}
\hline Sınır Bölgesi & Baskın Ağ Dokusu (3 Bileşenli) & Baskın Ağ Dokusu (4 Bileşenli) \\
\hline Türkiye-Gürcistan Sınır Bölgesi & $\begin{array}{l}2 \text { ve } 4 \text { Numaralı dokular baskın } \\
\text { dokular olarak tespit edilmiştir. } \\
\text { Ağın Geçişsenlik ve Merkezilik } \\
\text { (otorite) karakteri ön plana } \\
\text { çıkmaktadır. }\end{array}$ & $\begin{array}{l}\text { Ağda } 4 \text { Bileşenli baskın doku } \\
\text { tespit edilememiştir. Ilişkiler } \\
\text { coğrafi olarak tek ve güçü } \\
\text { merkezler aracılığı ile } \\
\text { gerçekleşmektedir. }\end{array}$ \\
\hline $\begin{array}{l}\text { Türkiye-Yunanistan, } \\
\text { Bulgaristan Sınır Bölgesi }\end{array}$ & $\begin{array}{l}4 \text { Numaralı doku baskın dokular } \\
\text { olarak tespit edilmiştir. Ağda } \\
\text { merkezilik karakteri ön plana } \\
\text { çıkmaktadır. } 3 \text { adet ülke sınırı } \\
\text { olmasına rağmen bir } \\
\text { geçişkenlik tespit edilememiştir. }\end{array}$ & $\begin{array}{l}\text { Bileşenli analizde } \\
\text { yerleşimlerin merkezilik ve hub } \\
\text { (dağıtıcı merkezlik) özellikleri } \\
\text { baskın ağ dokusu olarak ortaya } \\
\text { çıkmaktadır. }\end{array}$ \\
\hline $\begin{array}{l}\text { Türkiye Doğu ve Batı Sınır } \\
\text { Bölgeleri }\end{array}$ & 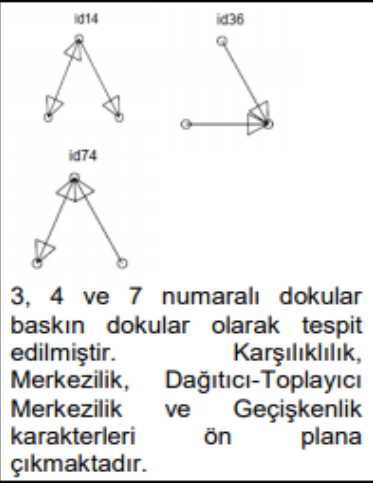 & $\overbrace{0}^{\mathrm{id} 2184}$ \\
\hline
\end{tabular}

Şekil 7. Sınır bölgesi 3 ve 4 bileşenli ağ dokusu

Sınırdaki ağ dokuları tespit edilirken klasik ağ dokusu tespitine ek olarak 7 aşamalı bir süreç izlenmiştir. Analizin ilk aşamasında ağ merkezilikleri hesaplanmış ve baskın olan merkeziliğe sahip yerleşimi ortaya çıkarmak üzere bağ sayısına göre bir indirgeme yapılmıştır. Ardından ağırlık parametresi olarak nüfus parametresi eklenmiştir. Sonrasında ağırlıktan bağımsız olarak hesaplanan temel ağ dokuları tespit edilmiştir. Ardından elde edilen temel ağ 
dokuları ile merkezilik analizi çalışmaları birleştirilerek yerleşmelerin coğrafi konumları ile çakıştırılmak suretiyle sınır ağı dokuları her bir sınır bölgesi için elde edilmiştir (Şekil 8).

Sınırdaki ağ dokusu

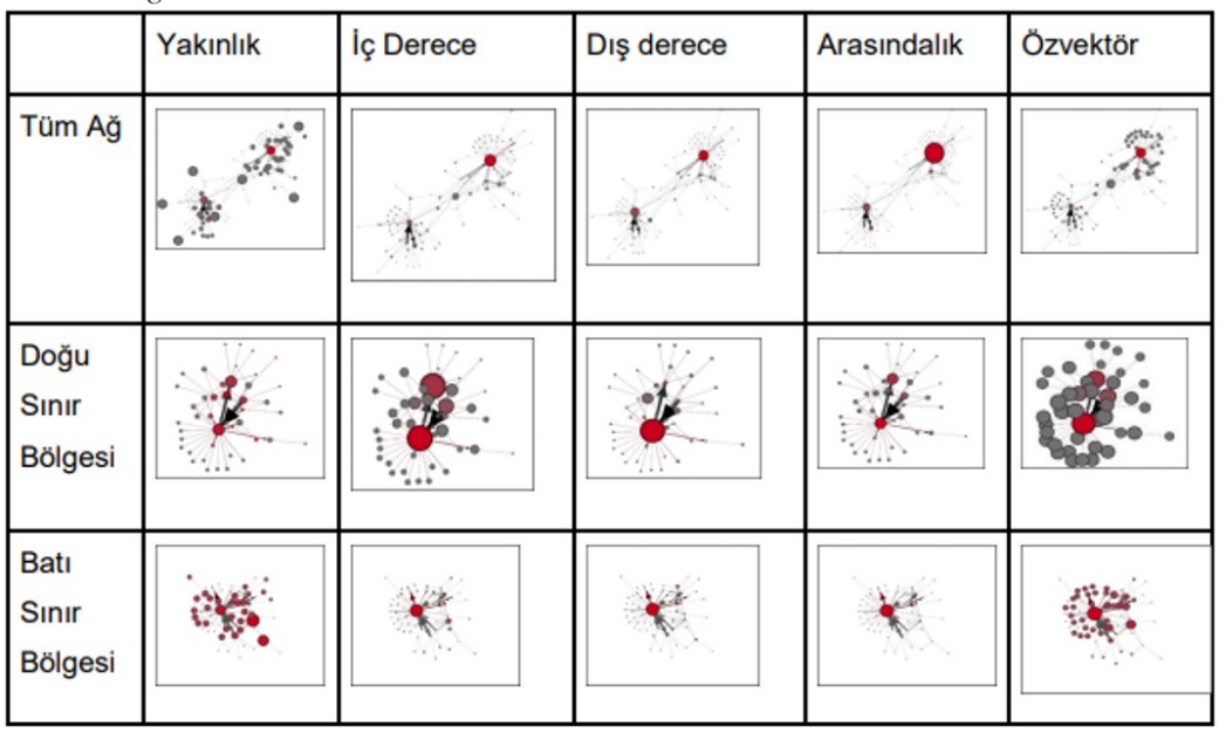

Merkezilik sonuçlarının bağ sayısı çerçevesinde indirgenmesi

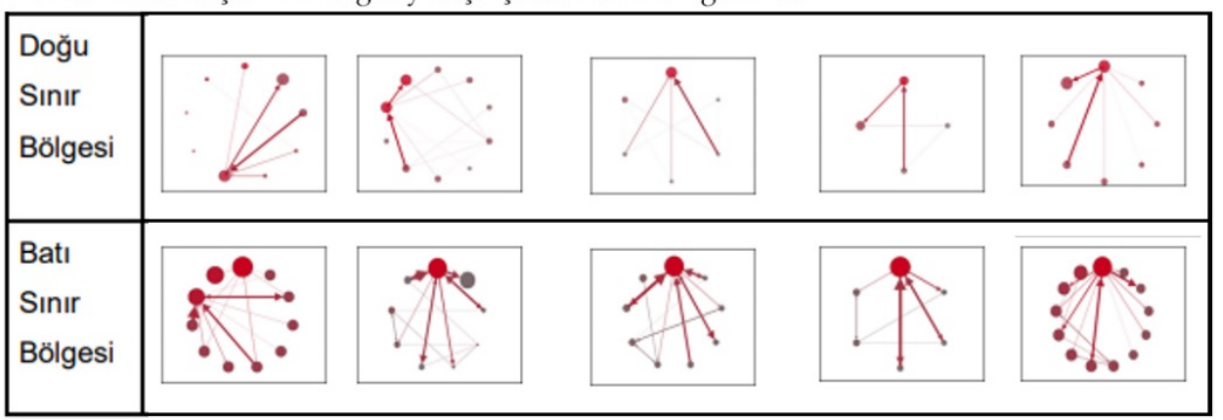

Şekil 8. Sınırdaki ağ dokusu ve merkezilik sonuçlarının bağ sayısı çerçevesinde indirgenmesi

Temel ağ dokusu ile tespit edilebilecek 3 bileşenli tüm olasılıklar ve sınır bölgesi analizinde baskın karakterli yerleşmeler ve aralarındaki ilişkinin ortaya konulabilmesi için aktarma merkezi (hub), otorite, geçişkenlik ve karşıllklllık kavramları çerçevesinde elde edilen sonuçlar sınıflandırılmıştır. Buna göre 3 bileşenli ağ dokusu sonuçlarına göre aktarma merkezi görevi gören yerleşmeler Türkiye'den Edirne ve İpsala; Bulgaristan'dan Haskova, Svilengrad, 
Harmanlı ve Simeonograd ve Yunanistan'dan ise Komaros'tur. Otorite (bölgesel merkez) potansiyeli olan yerleşimler ise Türkiye'den Edirne, Keşan; Yunanistan'dan Komotini ve Kastaniastır. Geçişkenlik özelliğine sahip yerleşmelerde ise Türkiye'den Edirne; Keşan Yunanistan'dan Dedeağaç öne çıkmaktadır. Bölgesel merkez nitelikteki kentlerin içinde olduğu karşılıklılık ve geçişkenlik içeren yerleşmeler Edirne ve Keşan kentleridir.

Sınırın ilk 100 km'lik kısmında ikamet eden ve sınırın diğer tarafı ile etkileşimi olanların hedef kentleri ile ilişki yoğunluğu hesaplanarak sınır bölgesinin etki alanı ve merkezleri haritası elde edilmiştir (Şekil 9). Buna göre Türkiye-AB sınırının ilk 50 km'si çok yoğun olmak üzere 100 km'lik çapı içinde yoğunlaşmanın devam ettiği $200 \mathrm{~km}$ civarında bulanık sınırların ortaya çıtığı bir etkileşim alanı tanımlanmaktadır. Diğer yandan sınır bölgesinin etkileşim alanı dışında sınır ülkelerinin büyük kentleri (Sofya, Bükreş, Selanik ve İstanbul) sınır bölgesi ile ilişki içerisinde bulunmaktadır.
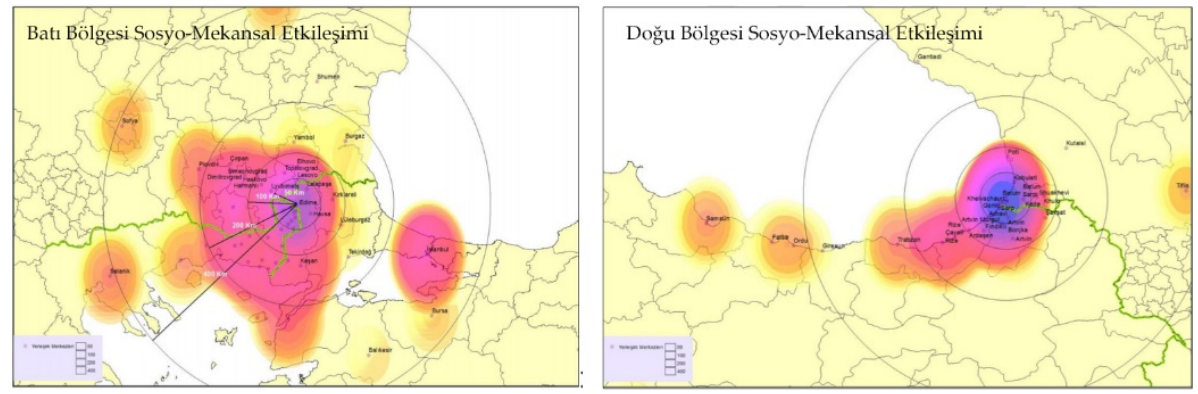

Şekil 9. Sınır bölgeleri sosyo-mekânsal etkileşimi

Türkiye-Gürcistan sınır bölgesinde ise sınırının ilk 50 km'si çok yoğun olmak üzere 100 km'lik çapı içine alacak şekilde homojen sayılabilecek lineer bir yoğunlaşma sınır bölgesinin bulanık sınırların belirlemektedir. Bu lineer etkileşim alanı Türkiye tarafında Rize, Trabzon, Ordu ve Samsun'a kadar ulaşmakta, Gürcistan tarafında ise sınır bölgesinin merkezi Batum'un yanı sıra Tiflis gibi Gürcistan'ın büyük kentleri sınır bölgesi ile ilişki halinde bulunmaktadır. Diğer yandan sınır bölgesinde yer alan ve sınıra yakınlığı ve geçiş avantajı nedeniyle sını ötesi ile yoğun ilişki içerisinde ufak yerleşimler yer alabilmektedir. Türkiye-Gürcistan sınır bölgesi iki ülke arasındaki idari yapılanma türlerinin farklılığı, yerleşmelerin morfolojik özellikleri, topoğrafik yapının etkileri, sınır geçişinin kolaylığı gibi bölgeleri birbirinden farkl1laştıran bir kimliğe sahiptir. Coğrafi koşulların etkisi ile doğrusal bir hat boyunca yer alan yerleşmelerin ulaşım avantajlarını kullanarak daha merkezi 
konuma geldikleri ortaya çıkmıştır. Diğer yandan doğu sınır bölgesindeki en merkezi ve tekil ağ aktörü nüfus, ekonomik yapı ve ulaşım gibi avantajları ile Gürcistan tarafında yer almaktadır.

A $\breve{g}$ analizlerinde ortaya çıkan bir diğer önemli bulgu, sınır bölgesinin merkezi yerleşmesinin her zaman ekonomik olarak güçlü tarafta olmadığıdır. Ülkelerin ekonomik gayri safi milli hasılaları üzerinde yapılan değerlendirmelerde, Türkiye Gürcistan' dan yaklaşık 50 kat daha büyük bir GSMH'ya sahip olmasına rağmen, sınırdaki yerleşim sistemi Batum'u bölgenin merkezi ve tekil ağ aktörü haline getirmiştir. Türkiye tarafındaki yerleşimlerin bölgedeki merkezilik değerleri düşük olduğundan tekil ve baskın bir aktör bulunmamaktadır.

\section{Sinır Bölgesi Yönetişimi}

Değişen ihtiyaçlar ile birlikte sınır bölgelerinde yönetişim yapısı değişiklik gösterirken sınırların daha az katı hale gelmesiyle birlikte, geleneksel katı idari sınır yapıları da bulanık bir yapıya doğru evrilmektedir. Sınır bölgesinde yönetişim; karmaşık sosyal ve idari yapıları ile farklı yapıdaki aktörleri artı değer üretme amacıyla bir arada tuttuğundan, ulusal düzeyde ele alınan yönetişim kavramından farklılaşmaktadır. Sınır bölgelerinde yürütülen işbirlikleri düzeyinde uygulanan yönetişim yapıları; kendi kendine organize olabilme, koordinasyon ve etkileşim, stratejik zekâ ve öğrenmeye açıklık gibi göstergeler ile karşılaştırmalara konu olabilmektedir. Bu sebeple, her bölgenin kendi işbirliği ve kendi iyi yönetişimini gerçekleştirmesine yönelik olarak ortaya konulacak yöntem, bölgenin içsel dinamiklerini, özgünlüklerini, kapasitesini, kültürel ve coğrafi konumunu, ekonomik faaliyetlerini, sosyal ilişkilerini ve ağlarını içerecek şekilde kurgulanmalıdır. Çok aktörlü mekânlar olmalarından dolayı sınır bölgelerinde koordinasyon, işbirliği ve ortak aktiviteler oluşturulması tamamıyla başarılı yönetişim model ve süreçlerine bağl1dır (Scherer ve Zumbusch, 2011). Bu kapsamda komşu ülkelerle etkileşim ve uyumun artmasını sağlayacak yönetişim modeli ve politika önerileri, karşılıklı etkileşim ve uyumun gelişme potansiyeli olduğu bölgeleri ön plana ç1karacaktır. Uygulanabilecek yönetişim modeli, bu işbirliklerinin başarısını doğrudan etkileyerek, bölgelerin kalkınması açısından önemli bir araç olacaktır.

$\mathrm{AB}$ deneyimleri ile birlikte gelişen çok katmanlı yönetişim, interaktif yönetişim, yumuşak yönetişim ve sınır ötesi yönetişim gibi yönetişim türlerinin uygulama modelleri, $\mathrm{AB}$ 'nin entegrasyon üst hedefine uygun bir kurgu çer- 
çevesinde şekillenmiştir. Bu durumda entegrasyon üst hedefinden uzak ancak ortak hedefleri olan, ekonomik, sosyal, idari ve mekânsal ilişki düzeyleri çeşitlilik gösteren sınır bölgelerine yönelik sınır bölgesi yönetişim yaklaşımının eksikliği ortaya çımaktadır.

Çalışma alanındaki sınır bölgeleri için yönetişim yaklaşımı yönetişim ve sınır dinamikleri ile birlikte yönetişimin ve sınırın çok boyutlu dinamik yapısı ayrı ayrı değerlendirilmeye alınmıştır. Her bir sınır bölgesi için sınır bölgesinin ortak yönetişim özellikleri tespit edilerek birbirleri ile ilişkileri sorgulanmıştır. Buna göre her bir sınır bölgesine özgü olarak tanımlanabilecek yönetişimin, sınır ekseni ve yönetişim ekseni adı verilen iki boyutla ele alınabileceği tartışılmıştır. Bir tarafta, bölgenin içsel dinamikleri, özgünlük kapasitesi, ekonomik faaliyetleri, sosyo-kültürel ilişkilerinin yanı sıra sosyo-mekansal ağlar ve geçirgenlik fonksiyonunun tanımlandığı sınır ekseni; diğer tarafta aktörler, süreçler, kurumlar, ortak normlar ve sinırlılıkların yer aldığı yönetişim ekseni, ortak yönetişim aralığını tanımlayarak, yönetişim çerçevesi çizilmesine katkı sağlanmıştır.

Sınırda yönetişim bölgenin içsel dinamikleri, özgünlük, kapasite, kültürel ilişkiler, coğrafi konumu, ekonomik faaliyetler, sosyal ilişkiler ve ağlar değerlendirilerek kurgulanmıştır. Bu kurgu içinde, sınır bölgeleri için temelde dinamik bir ortak yönetişim aralığı olduğu ve katmansal düzeydeki parametrelerin bu aralıkta iki bölge arasındaki ilişki düzeyine göre şekillendiği savunulmaktadır. Sınır bölgelerinde tam bütünleşme düzeyinden, ilişkinin olmadığı düzey aralığı içerisinde bir ilişki bulunmaktadır. Sınırdaki yönetişim bu ilişki aralığında bir yerde bulunabilir. Bu durum o bölge için bir yönetişim modeli üretmek için engel olmamaktadır. Diğer yandan kırılgan yapısından dolayı sınırdaki yönetişim bir denge mekanizmasına benzetilmiştir. Dengenin bir tarafında ekonomik, sosyal, kültürel boyuttaki ulusal devletler dışı aktörler yer alırken, diğer tarafında egemenlik alanları, ulusal hassasiyetler, öteki algıları gibi ortak yönetişim aralığını daraltacak nitelikte etkenler bulunmaktadır. Bu dengenin ülke içi dinamikler, ülkeler arası siyasi ilişkiler, yerel düzeydeki benzer ilişkiler ile olumlu veya olumsuz yönde değişebilmesi çok olasıdır. Kamu politikaları açısından bir değerlendirme yapıldığında, Türkiye tarafından sınır bölgesi dinamiklerini de içine alan üst ölçekli bütüncül bir stratejik çerçeve çizilmesi önem taşımaktadır. Buradaki temel hedef, ağ analizlerinde ortaya çıkan asimetrik ilişki deseninin daha dengeli simetrik ilişki desenine doğru çevrilmesi olmalıdır. 


\section{Sonuç ve Tartışma}

Bu çalışma, coğrafi olarak ulus devletlerin çeperlerinde yer alan sınır bölgelerinin, bölgesel düzeyde etkileşimin/geçirgenliğin artması ile merkezi hale gelmeleri ve yerleşmeler arası artan sosyo-mekânsal etkileşimle bağlantılı ağsal ilişkilere dayalı, sınır bölgeleri özelinde bir yönetişim çerçevesi geliştirilmesi tartı̧malarını içermektedir. Söz konusu çerçevenin geliştirilmesi için öncelikle sınırın geçirgenliği ölçülerek, geçirgenlik düzeylerine göre seçilen bölgelerde saha çalışması ile veri toplanması hedeflenmiş, elde edilen verilerden sosyal ağ analizi yapılarak ağın işleyişi ve dokusu ortaya çıkarılmıştır. Sınır geçirgenlik endeksi, ağ analizleri ve ağ dokusu sonuçlarının girdi sağladığ sınır bölgelerine özgü bir ortak yönetişim aralığının tanımlanması, sınır bölgeleri için sadece entegrasyon durumunda geçerli bir yönetişim çerçevesi tanımlamanın ötesinde bölgenin özelliklerine göre şekillenen özgün bir yönetişim bir çerçevesi sunmaktadır.

Bu çerçevede öncelikle sınır bölgelerinin etkileşim düzeylerinin bütüncül bir şekilde ölçülmesine yönelik yeniden tanımlanan geçirgenlik kavramı ile, farklı geçirgenlik düzeylerine sahip sınır bölgeleri için ulusal düzeyde ortak bir değerlendirme çerçevesi ortaya konulmaktadır. Seçilen $A B$ ve Gürcistan sınır bölgesinde ağ yaklaşımından elde edilen somut sonuçların analitik olarak yorumlanması, sınır bölgelerindeki merkezi yerleşimlerinin ağ karakterlerine bağlı olarak farklılaştığını ortaya çıkarmıştır. Literatürde kullanılan 50 ve 100 km'lik sınır bölgeleri tanımlarının fonksiyonel bölge sınırları değerlendirmesi ile uyumlu olduğu, ancak sınır bölgelerinin etki alanının bunun ötesine geçebildiği tespit edilmiştir. Sınırın mekânsal etki alanının dışında bulunan ulusal düzeyde merkezi özellik taşıyan yerleşmelerin de sınır ile belirli derecelerde ilişkilerinin olduğunu ortaya çıkarmıştır. Diğer yandan ağın mekândan bağımsız olarak ortaya çıkan gruplaşma düzeylerinin büyük ölçüde mekânsal doku ile ilişkili olduğu saptanmış ve sınır kapılarının ağın gruplaşma düzeyinin oluşmasında önemli bir etkiye sahip olduğu ortaya konulmuştur.

Sınırın merkez-çeper ilişkisi ile kurgulanan sınırlayıcı fiziki bir hattan ağ tabanlı ilişkiler üzerinden yakınsama bölgelerine dönüşmesi ile birlikte sınır ötesi akımlar ve ilişkiler artmakta, kültürel ve kurumsal değişiklikler ortaya çıkmakta, ekonomik büyüme, rekabet ve teknolojik gelişme hızlanmakta ve bu değişimler yeni yönetişim pratiklerinin ortaya çıkmasını zorlamaktadır. Bu çerçevede çalışmada sınır bölgesi yönetişimi, bölgenin içsel dinamikleri, özgünlük, kapasite, kültürel ilişkiler, coğrafi konum, ekonomik faaliyetler, 
sosyal ilişkiler ve ağsal ilişkiler birlikte tartışlarak, sosyo-mekânsal özgünlükleri içerecek şekilde yeniden tanımlanmıştır. Sınır geçirgenlik endeksi, makro ve mikro ağ göstergeleri ve ağ dokusu çalışmalarının girdi sağladığ sınır bölgelerine özgü bir ortak yönetişim aralığ1 tanımlanarak, bu özel bölgeler için sadece entegrasyon durumunda geçerli bir yönetişim çerçevesi önermenin ötesinde, bölgenin özelliklerine göre şekillenen özgün bir yönetişim çerçevesi tanımlanabileceği ortaya konulmuştur.

Sınır bölgelerinin idari olarak çok katmanlı yapılardan meydana gelmesi, farklı kurumsal yapılar ve pratiklerin olması, geleneksel güvenlik odaklı politikaların baskın olması; ekonomik olarak sosyal ve ekonomik yaşamın kutuplaşmalarının olması, kendi kendine organize olabilen yapıların bulunması; sosyal olarak ulusal hassasiyetlerin varlığı, koordinasyon ve işbirliği eksikliği, sosyal ağlar ve akımların etkilerinin olması ve bölgeler arasında teknik altyapı farklılıklarının bulunması sınır bölgelerinin karşılaştıkları temel sorunlar olarak ortaya çıkmaktadır. Söz konusu sorunlar, farklı kurumsal-idari yapılar, farklı öncelikler ve bölgelere özgü kırılganlıklar değerlendirildiğinde sınır bölgesinde yönetişim modeli için bazı ön şartların asgari düzeyde sağlanması gerekmektedir. Sınır bölgesi için ortaklaşılmış vizyon ve hedeflere ulaşmak için üst düzey politik destek ve uzun dönemli taahhütler ilk ön şarttır. Ancak bu noktada yerelin dinamikleri devreye girebilmektedir. Yerel yönetimlerin Housen ve Couriel, (1994:2)'nin belirttiği gibi “etkin uluslararası kapasiteye sahip olması ve işbirliğini yürütebilmesi" gerekmektedir. Bu noktada yerel yönetimlerin de ortak vizyonu sahiplenmesi ve işbirliklerinden fayda sağlayacağı öngörüsü olmalıdır. Bu anlamda ortak yönetim/yönetişim aralığı, tarihsel, kurumsal ve politik ortamın değişkenliğine istinaden kabuk değiştirebilen bir yapıda tanımlanmaktadır.

Ulusal politikalar ile şekillenen, üzerinde sosyal ve ekonomik ilişkiler kurulan ve mekânsal eşikler ile yönlenen yakınsama mekânları olarak sınır bölgeleri, politik ve idari yapıların egemenlik alanları olarak çizdikleri çizginin ötesinde bir etkileşime konu olmaktadır. Sınırları, idari ve ülke sınırlarından çoğu zaman ayrışan dinamik ve bulanık bir yapıda olan bu bölgeler, ulusal sınırlar ve egemenliklerin sarmaladığı bir alanda istikrarın çoğunlukla yerel aktörlerden bağımsız olarak dalgalandığı bir karakter sergilemektedir. Sınır bölgelerinde kurumsal düzeyde yerel aktörlerin içinde olduğu bir katılım platformu eksikliği büyük ölçüde hissedilmektedir. Bu çerçevede yerel düzeyde katılıma odaklı sürekli bir yönetişim platformu kurularak iletişim köprüsü kurumsallaştırılması sürekliliğinin sağlanması önem taşımaktadır. Sınır bölgelerinin kırılgan yapısı, hassas dengelerin olması bu bölgelerde kuvvetli 
bir yönetişim çerçevesinin sürdürülmesine olanak sağlayamamaktadır. $\mathrm{Bu}$ çerçevede güçlü bağların ortaya çıkardığı yerleşimler arasında öncelikli olmak üzere, sürekliliği sağlanan bir kurumsallaşmanın sınırın her iki tarafı için de faydalı olacağı değerlendirilmektedir.

Tüm bunlar değerlendirildiğinde; sınırların çeşitli mekânsal ölçekler üzerine kurgulanan sosyal kurumların karmaşık bir kümesi oldukları ve içinde üretildikleri ve anlam kazandıkları sosyal pratikler ve söylemlerle ilişkili oldukları görülmektedir. Buradan yola çıkarak sınırların bağlam-bağımlı yapılarının, ekonomik, sosyal, kültürel ve politik süreçler ve söylemlere gömülü olmalarının, farklı ve karmaşık kavramsal içerikler taşımalarına sebep olduğunu söylemek mümkündür. Bu anlamda genel bir sınır kuramı yaratmak yerine, sınırların politik, sosyo-ekonomik ve mekânsal ele alışlarını ve ilişki düzeylerini ele alarak politika oluşturma, sınırların her ölçekteki karar mekanizmaları açısından kavramın anlaşılmasına katkı sağlayacaktır.

Teşekkür: Bu çalışma, TÜBİTAK-SOBAG tarafindan desteklenen 114K887 nolu projenin saha çalışması bulgularına dayalı olarak geliştirilmiştir. 


\title{
Extended Abstract
}

\section{Socio-Spatial Interaction and Governance in Border Regions: The Case of Turkey}

\author{
Emrah Söylemez ${ }^{5}$ \\ ORCID: 0000-0003-4150-3184 \\ Çiğdem Varol ${ }^{6}$ \\ ORCID: 0000-0002-2432-5745
}

This study discusses the governance approach in border regions by considering different methodological approaches within the complexity of social sciences field. The increase of permeability at the borders of the nation states has caused a more intense flow of goods and people compared to the past, and instead of being excluded places left in the periphery, border regions have become places of more central and important activities.

The multi-dimensional approach for the governance of border regions is discussed in three stages. First, the definition of border permeability is reconstructed in a socio-spatial context and a "Multivariate Border Permeability Index" is obtained by using national scale data. A comprehensive, systematic and integrated model for measuring the permeability across the land borders of nation states is produced despite the limitations in the available data types. While obtaining the index, fuzzy logic is used as a standardization method. The index, produced by 22 variables, differs from one-dimensional and abstract indeces used so far in the literature, since it reflects geographical and non-geographical data together by using the composite index methodology. This approach not only contributes to the theoretical framework, but also helps to guide public policies at national borders.

Secondly, the socio-spatial interactions in the border regions are analyzed with approaches focused on multi-dimensional network analysis and network metrics, macro- and micro-level network structures and patterns. In this process, the data are gathered by in-depth interviews with local institutions and organizations and surveys with households living on both sides of the

\footnotetext{
${ }^{5}$ Dr. Ministry of Environment and Urbanization, E-mail: emrah.soylemez@csb.gov.tr

${ }^{6}$ Prof. Dr., Gazi University, E-mail: cvarol@gazi.edu.tr

idealkent @ Kent Araştırmaları Dergisi (Journal of Urban Studies)

http://idealkentdergisi.com

Geliş Tarihi Received Date: 24.03.2020 Kabul Tarihi Accepted Date: 25.04.2020
} 
selected border regions (Turkey-EU/Greece and Bulgaria and Turkey-Georgia) which have high and moderate levels of permeability. The aim of the multi-dimesional network analyses is to develop comparative results in economic, social, administrative and spatial dimensions. According to the results obtained from the network analysis, it is revealed that the centralities of the settlements in the border regions differ depending on the character and pattern of the network. Correspondingly, it is determined that the definitions of border regions with a depth of 50 and $100 \mathrm{~km}$ from the borderline used in the literature are compatible with the evaluation of functional regional borders, but the area of impact goes beyond this measure. On the other hand, it is determined that modularity levels occurring in the network are largely related to the spatial pattern of the network. This demonstrated that border crossings have important effects on the clustering level of the network on the border. In addition, when the locational advantages of the settlements at the border region network are evaluated together with centrality, clustering and general network metrics, it is revealed that the settlements gain a high centrality if they have appropriate population, economic and social structure within their own country.

Finally; border region governance is redefined to include socio-spatial specificities by discussing the internal dynamics of the region, originality, capacity, cultural relations, geographical location, economic activities, social relations and network relations. Thus, a "mutually agreed governance framework" specific to the border regions is defined using the border permeability index, macro-micro network indicators and network patterns. Thus, it is revealed that a specific governance framework, which is not only valid in the case of integration but is shaped according to the characteristics of the region, can be defined for these special regions. The fragile nature of the socio-spatial relations in the border regions shows that a balance mechanism is needed in the search for a soft governance at the border. On one side of the balance, there are actors with economic, social and cultural characteristics outside the national states, while on the other there are factors that narrow the range of mutually agreed governance, such as sovereignty areas, national sensitivities, and perceptions for the other side of the border. The balance can change positively or negatively with the dynamics within the country, political relations between the countries, or relations at the local level.

Borders appear to be a complex set of social institutions built on various spatial scales and are associated with social practices and discourses in which 
they are produced. From this point of view, it is possible to say that the context-dependent structures of the borders are embedded in economic, social, cultural and political processes and discourses, causing different and complex conceptual contents. In this sense, instead of creating a general border theory, developing policies by addressing the political, socio-economic and spatial consideration and relationship levels of the borders will contribute to the understanding of the concept in terms of the decision mechanisms for borders at all scales.

\section{Kaynakça/References}

Anderson, J. ve O'Dowd, L. (1999). Contested borders: globalization and ethno-national conflict in Ireland. Regional Studies, 33, 681-691.

Baud, M. ve Schendel, W. (1997). Toward a comparative history of borderlands. Journal of World History, 8(2), 211-242.

Bauman Z. (2005). Liquid life. Cambridge: Polity Press

Blatter J. (2004). From 'spaces of place' to 'spaces of flows'? Territorial and functional governance in cross - border regions in Europe and North America, International Journal of Urban and Regional Research, 28(2).

Bonacich, P. (1972). Technique for analyzing overlapping memberships. Sociological Methodology, 4(1), 176-178.

Borgatti, S. P. (2005). Centrality and network flow. Social Networks, 27(1), 55-71.

Castel-Branco C. N. (2014). Growth, capital accumulation and economic porosity in Mozambique: social losses, private gains, Review of African Political Economy, 41(1), 26-48.

Castells, M. (1996). The rise of the network society, the information age: Economy, society and culture. Oxford, UK: Blackwell.

Diener, A., C. ve Hagen, J. (2012). Borders. A very short introduction. Oxford and NewYork: Oxford University Press.

Freeman, L. C. (1978). Centrality in social networks conceptual clarification. Social Networks, 1(3), 215-239.

Grosby, S. (1995). Territoriality: The Transcendental, Primordial Feature of Modern Societies. Nations and Nationalism, 1(1), 143-162.

Hansen, J. D., Johnson, A., Lacis, S., Lebedeff, P., Lee, D. ve Russell, G. (1981). Climate impact of increasing atmospheric carbon dioxide. Science, 213, 957-966.

Harrison, J. (2012). Configuring the new 'regional world': on being caught between territory and networks. Regional Studies, 47(1), 55-74.

Haselsberger, B. (2014). Decoding borders: appreciating border impacts on space and people. Planning Theory and Practice, 15(4), 505-526. 
Hidalgo, C. A. (2016). Disconnected, fragmented, or united? a trans-disciplinary review of network science. Applied Network Science, 1(6), 300-328.

Hooghe, L. (1996). Cohesion policy and European integration: building multi-level governance. Oxford: Oxford University Press, 126.

Housen-Couriel D. (1994). Some principles of cooperation in the management and use of international water resources. Tel Aviv:Tel Aviv University.

Jessop, B., Brenner, N. ve Jones, M. (2008). Theorizing sociospatial relations. Environment and Planning D: Society and Space, 26(3), 389-401.

Kolejka, J., Wiesława, Ź., Kateřina, B., Stanisław, C., Sylwia, D., Karel, K., Tomáš, K., Andrzej, R., Waldemar, S. ve Jana Z. (2015). Permeability of Czech-Polish border using by selected criteria. Geographia Technica, 10(1), 51-65.

Kolossov, V. (2005). Theorizing borders border studies: Changing perspectives and theoretical approaches. Geopolitics, 10, 606-632.

Kooiman, J. ve S. Jentoft (2009). Meta-governance: Values, norms and principles, and the making of hard choices. Public Administration, 87(4).

Krugman, P. R. (1992). Does the new trade theory require a new trade policy? The World Economy, 15(4), 423-442.

Martinez, P. (2004). "Noble" Tlaxcalans: Race and ethnicity in Northeastern New Spain: 1770-1810.USA:The University of Texas at Austin,

Milo, R. (2002). Network motifs: simple building blocks of complex networks. Science, 298(5594), 824-827.

Mitchell, J.C., (1969) The concept and use of social networks. (Ed. J.C. Mitchell), Social networks in urban situations: Analyses of personal relationships in Central African Towns içinde, Manchester University Press: England.

Nathalie, S. (2006). Permeability models for the monitoring of border crossings, içinde Schneiderbauer vd. Remote sensing from space - Supporting international peace and security - GMOSS Book, (1. Bsm). Springer.

Newman, D. (2003). On borders and power: a theoretical framework. Journal of Borderlands Studies, 18(1), 13-25.

Opsahl, T., Agnessens, F., ve Skvoretz, J. (2010). Node centrality in weighted networks: Generalizing degree and shortest paths. Social Networks, 32(3), 245-251.

Paasi, A. (2005). Generations and the 'development' of border studies. Geopolitics, 10(4), 663-671.

Painter J, (2008). Cartographic anxiety and the search for regionality. Environment and Planning A, 40 342-361

Popescu, G. (2006). Geopolitics of scale and cross border cooperation in Eastern Europe: the case of Romanian-Ukranian-Moldovan borderlands, Aldershot Ashgate. 35-51.

Rhodes, R. A. W. (2007). Understanding governance: Ten years. Organization Studies, $28,1243$.

Sassen, S. (2001). The global city, (2. bsm). NJ: Princeton University Press, Princeton. Scott, J. (2000). Social network analysis: A handbook. London: SAGE Publications. 
Scott, J. W. (2012). European politics of borders, border symbolism and cross-border cooperation. T. M. Wilson ve H. Donnan (Ed.), A Companion to Border Studies, içinde (s.83-99).Chichester: Wiley-Blackwell.

Shen-Orr, S. S., Milo, R., Mangan, S., ve Alon, U. (2002). Network motifs in the transcriptional regulation network of Escherichia coli. Nature Genetics, 31(1), $64-68$.

Starr, H., ve Thomas, G. (2001). The nature of borders and conflict: Revisiting hypotheses on territory and war. 2001 annual meeting of the American Political Science Association, San Francisco.

Stephenne, N. ve Pesaresi, M. (2006). Spatial permeability model at the European Union land border, EUR report 22332 (Luxembourg: European Commission / DG-JRC / IPSC).

Tekeli, İ. (2004, Haziran). Katılımcı demokrasi, sivil ağlar ve sivil toplum kuruluşları. 15. STK Sempozyumu. İstanbul.

Van Houtum, H. (2005). The geopolitics of borders and boundaries. Geopolitics 10(4), 672-679.

Waterhout, B. (2010). Soft spaces and governance: The transformation of planning, 24. AESOP Konferansl, Helsinki, 7-10 Temmuz 2010. 